Baydaş, M. ve Eren, T. (2021). "Finansal Performans Ölçümünde ÇKKV Yöntem Seçimi Problemine Objektif Bir Yaklaşım: Borsa İstanbul'da Bir Uygulama”, Eskişehir Osmangazi Üniversitesi iỉß Dergisi, 16(3), 664 - 687.

Doi: 10.17153/oguiibf.947593

Başvuru : 03.06.2021 Kabul: 16.07.2021

Araştırma Makalesi/Research Article

\title{
Finansal Performans Ölçümünde ÇKKV Yöntem Seçimi Problemine Objektif Bir Yaklaşım: Borsa İstanbul'da Bir Uygulama
}

\author{
Mahmut Baydaş ${ }^{1}$ \\ Tevfik Eren ${ }^{2}$
}

\begin{abstract}
Finansal Performans Ölçümünde ÇKKV Yöntem Seçimi Problemine Objektif Bir Yaklaşım: Borsa İstanbul'da Bir Uygulama
\end{abstract}

Öz

Çok kriterli karar verme (ÇKKV) paradigmasının amacı en uygun uzlaşık alternatifi seçebilmektir. Oysa aynı karar matrisi kullanıldığında bile ÇKKV yöntemlerinin farklı sonuçlar üretebildiği de bir gerçektir. Bu farklı sonuçların karşılaştırılabilirliği için önerilen doğrudan bir ölçüt olmamasına rağmen dolaylı bir vekil ölçüt üzerinden ÇKKV yöntemlerinin göreceli üstünlükleri objektif olarak ortaya konabilir. Örneğin bir firmanın ÇKKV yöntemi ile ölçülen finansal performansı (FP) için aynı firmanın eşzamanlı hisse senedi getirisi (HG) dolaylı bir doğrulama ölçütü olarak önerilebilir. Çalışmada toplamda dört farklı yöntem HG ölçütü üzerinden karşılaştırılmıştır. Uygun olan yöntem tüm baz dönemlerde HG ile daha yüksek korelasyon sağladığı için bu koşullarda karar vericiye önerilmiştir.

Anahtar Kelimeler: Finansal Performans, ÇKKV, Hisse Getirisi, Spearman Korelasyon Katsayısı

JEL Kodları: G30, M21, L25, C44
A Different Approach to the Selection of MCDM Method for Financial Performance Measurement: An Application in Borsa Istanbul

\section{Abstract}

The common goal of multi-criteria decision-making (MCDM) methods is to choose the best alternative. On the other hand, it is a fact that MCDM methods can produce different results even though they use the same decision matrix. Although there is no direct criterion proposed for the comparability of these different results, the relative advantages of MCDM methods can be demonstrated over an indirect surrogate criterion. As in the example in this study, the concurrent stock return (SR) of the same firm can be used as an indirect criterion for the financial performance (FP) measured by the MCDM method. In the study, four different methods were compared over the SR criterion. Since the appropriate method provides a higher correlation with HG in all base periods, it is recommended to the decision-maker in these conditions.

Keywords: Financial Performance, MCDM, Stock Return, Spearman Correlation Coefficient

JEL Codes: G30, M21, L25, C44

\begin{tabular}{|c|c|}
\hline $\begin{array}{c}\text { Araştırma ve } \\
\text { Yayın Etiği } \\
\text { Beyanı }\end{array}$ & Bu çalışma bilimsel araştırma ve yayın etiği kurallarına uygun olarak hazırlanmıştır. \\
\hline $\begin{array}{c}\text { Yazarların } \\
\text { Makaleye } \\
\text { Olan Katkıları }\end{array}$ & Çalışmanın tamamı iki yazar ile birlikte oluşturulmuştur. \\
\hline Çıkar Beyanı & Yazarlar açısından ya da üçüncü taraflar açısından çalışmadan kaynaklı çıkar çatışması bulunmamaktadır. \\
\hline
\end{tabular}

\footnotetext{
${ }^{1}$ Öğr. Gör. Dr. Necmettin Erbakan Üniversitesi, Uygulamalı Bilimler Fakültesi, Muhasebe ve Finans Yönetimi Bölümü, mbaydas@erbakan.edu.tr

2 Dr. Öğr. Üyesi, Necmettin Erbakan Üniversitesi, Uygulamalı Bilimler Fakültesi, Muhasebe ve Finans Yönetimi Bölümü, teren@erbakan.edu.tr
} 


\section{Giriş}

Günümüzün dinamik piyasa koşullarında öncelikle firmaların varlıklarını sürdürebilmeleri ve mümkünse performanslarını daha iyi noktalara götürmeleri beklenir. Performansta kilit rol oynayan değer yaratıcı ve aşındırıcı unsurlar farklı faktörlerin etkisiyle değişebilmektedir. Üretilen değer ile kritik bir ilişkisi olan finansal performans (FP) bileşenleri bu anlamda ölçüm söz konusu ise daha dikkatli ve tekrar ele alınabilmektedir. Bu durum performansın belli bir zaman kesiti için dinamik bir yapıya sahip olduğunu da gösterir. Dolayısıyla firmayla ilgili taraflar amaç odaklı gerçek performansı merak etmekte ve araştırmacılar belirsiz olan en iyi (pareto optimal) performans ölçümünün koordinatlarını tespit etmeye çalışmaktadır. Gerçek bir FP, işletmeyle ilgili tarafların çokluğu dikkate alındığında oldukça göreceli gelebilir. Tarafların farklı menfaatleri onları ortak bir paydada birleştirme noktasında zorluk yaratır. Bu noktada tüm tarafları ilgilendiren bir nokta olarak hissedar değeri önemli bir paydaştır. FP, hissedar değeri odaklı olarak hesaplandığında seçilecek kriterler de elbette bundan etkilenecektir. Buna göre değer yaratan kriterler fayda yönlü olarak ve değer aşındıran kriterler ise maliyet yönlü olarak sınıflandırılabilir. Diğer bir husus daha önceki pek çok çalışmadan farklı olarak hissedar değerine odaklı bir FP ölçümünde, baz dönemdeki statik değerler yerine değişim değerleri öncelikli olarak tercih edilebilir. Çünkü hissedar değerinin net ifadesi olan hisse getirisi esasen fiyatın yüzdesel değişimini ifade eder. Dahası bunun alternatifi olan fiyat ile statik rasyoların ilişkisi benzer ve doğrusal bir yapıda değildir. Dolayısıyla FP'nin statik unsurları zaman kesiti olarak (örneğin bir yıllık) hissedar değeriyle uyumlu olmayabilir. Birisi statik iken diğeri değişimsel bir formdadır. Kısaca kriterlerin seçimi ve formu FP ölçümünde önemlidir.

FP kriterlerinin seçim kararından sonraki aşama olarak karşımıza FP‘nin hangi metodla ölçüleceği çıkmaktadır. Performansı temsil eden yegane bir kriter olmadığından ve kriterlerin sayısı ve önemi de değişebildiğinden çoklu kriterlerle performans ölçümü rasyonel bir çözüm olmaktadır. Bu durumda performans ölçümü için sayıları günümüz itibariyle 100'ü aşkın ÇKKV yöntemleri karar vericiler (KV) açısından uygun alternatiflerdir (Danesh vd., 2017: 282). Hangi ÇKKV yönteminin daha iyi olduğu ya da seçilmesinin daha uygun olduğu ile ilgili net ve tatmin edici bir cevap bulunmamaktadır. Konu tartışmalı ve adeta bir bulmaca gibidir. Çoğu zaman yöntem bilimciler açısından cevabı zor ya da yoktur (Triantaphyllou, 2000: 199-265). Sonuçta tüm ÇKKV yöntemleri aynı amaca hizmet eder: En iyi olan alternatifi (ve sıralamayı) bulmak ve önermek. Ne var ki en iyi olan alternatif önerisi, yönteme göre farklı olabilmektedir. Bu durum KV'ler için ÇKKV metodu tercihi yaparken zaman zaman bir endişe kaynağı olabilmektedir. KV'nin öznel olarak inisiyatif aldığı veya müdahale ettiği noktalardan biri olan "ÇKKV seçimi" esasen yaygın ve kronikleşmiş bir problemdir. Bu seçimde yaygınlık, benimsenme, popülerlik ve yazılım desteği sağlanma kolaylığı gibi sübjektif faktörler etkili olabilmektedir. Diğer taraftan ÇKKV yöntemlerinin zaman zaman yetenek ve kapasiteleri açısından somut olarak değerlendirilebildiği de bir gerçektir. Ama ürettikleri sonuçlar açısından tatmin edici objektif bir değerlendirmenin yapılabildiği şüpheli veya tartışmalıdır. Çünkü ÇKKV yöntemlerinin karşılaştırmaya esas olacak şekilde yarattıkları değer veya sonuç anlamında bir problemi çözebilme derecesinin somut bir ölçüsünü göstermek halen zordur.

ÇKKV yöntemlerinin doğrudan yarattıkları değer bilinemiyorsa ve bundan dolayı karşılaştırılamıyorlarsa dolaylı yarattıkları bir değer dışsal ölçüt olarak ele alınabilir. Bunun iyi bir yolu ÇKKV metodlarının kendilerine anlamlı benzerliği olan gerçek yaşamdan vekil bir dışsal sıralama ile ilişki üretebilme kapasitesini ölçmektir. Somutlaştırmak gerekirse ÇKKV 
yöntemleriyle hesaplanmış bir finansal performans ile hisse senedi getirisi sıralamaları arasındaki benzerlik ilişkisi, yöntemleri kıyaslamak için referans bir çözüm olabilir. Çünkü iki faktör hem eşzamanlı olarak ilişkilidir ve hem de aynı firmaya ait değerlere sahiptir. Dahası bu iki faktörün benzerliği olsa da aynı şeyi ifade etmez. Çünkü biri firmanın sistematik olmayan risk boyutunu ifade eder ve kontrol alanındadır. Diğeri ise firmanın doğrudan kontrol edemediği sistematik risk boyutunu ifade eder. FP içsel performansı ve HG ise aynı firma için dışsal performansı ifade eder.

Bu noktada hisse senedi ile FP arasındaki benzerlik ilişkisini daha güçlü ortaya koyan ÇKKV yöntemi karar vericiye önerilebilir. Var olan bir benzerliği bazı yöntemlerin düşük bazı yöntemlerin yüksek derecede sağlaması ÇKKV yöntemleri için ilgi çekici bir durumdur. Bu durum bazı yöntemlerin gerçek yaşamı daha iyi yakaladı̆̆ı/modellediği anlamına gelir ki ÇKKV yöntemleri için istenen de tam olarak budur.

Söz konusu yaklaşımı test etmek için öncelikle önemli bir endüstri olan Borsa İstanbul Imalat alt sektörlerinden olan Metal Eşya sektöründe yer alan 25 firmanın yıllık finansal performansı ölçülecektir. Belirli karar kriterleri baz alınarak TOPSIS ve SAW yöntemleri kullanılacaktır. Çalışma birer yıllık performans dilimlerinden oluşan toplam 5 yıllık 2015-2019 dönemlerini kapsamaktadır. Bir sonraki aşamada ise hisse senedi getirisi ile finansal performansın ilişkisi Spearman korelasyon katsayısı ile hesaplanacaktır. Popüler bir yöntem olan TOPSIS ve klasik bir yöntem olan SAW yöntemleri, HG ile olan korelasyon sonuçları açısından karşılaştırılacaktır. Bazı ÇKKV yöntemlerinde KV müdahalesine daha açık bir hesaplama süreci vardır. Bu yöntemler, KV'den varsayım, eşik değer veya tercih fonksiyonlarını belirli kısıtlarda, istedikleri gibi belirlemelerini isteyebilirler. Tersine bazı yöntemlerde ise KV müdahalesi ya da katılımı daha azdır (TOPSIS, SAW vb.). Dolayısıyla hangi yöntem olursa olsun karar verici sonuçları doğrudan etkileyecek belirli bir manevra gücüne sahiptir. Sübjektif KV kararları etkili olduğunda objektif ve optimale yakın bir sıralama elde etmek riske girebilir. Bu çalışmada kullanılan TOPSIS ve SAW yöntemlerinde KV'nin sonuçları etkileme olasılığı daha düşüktür. Çünkü bu yöntemler karar vericiden varsayım, eşik değer veya tercih fonksiyonu ayarlamasını beklemez. Diğer taraftan ağırlıklandırmada iki yöntem için de aynı katsayı değerleri kullanılacaktır. TOPSIS ile SAW arasında bir seçim yapmak gerekirse aktüel HG getirileri ile daha güçlü bir istatistiki ilişki yaratan yöntem KV'ye önerilebilecektir. Böylece daha önceki çalışmaların tersine ÇKKV yöntemi birey, uzman etkisi ile ya da öznel olarak değil, çalışmadaki bu yaklaşımla objektif biçimde ve otomatik olarak belirlenecektir. Ayrıca ÇKKV yöntemleri kapasite ve yetenekleri açısından değil ürettikleri sonuçlar açısından karşılaştırılacaktır. 


\section{Literatür}

\section{1. ÇKKV ile Ölçülen Finansal Performans}

Alternatif ÇKKV yöntemleri arasından hangisinin daha uygun olduğu sorusu literatür için bir bilmece olmaya devam etmektedir. Burada yöntemlerin çoğunun zaten benzer sıralama sonuçları verdiği akla gelebilir. Fakat sıralamaların benzer olması sıralamadaki en iyi alternatifin de aynı olduğu anlamına gelmemektedir. ÇKKV yöntemlerinin asıl amacı en iyi alternatifi belirlemektir. Dolayısıyla ÇKKV yöntemlerinin seçimine bağlı olarak en iyi olan alternatif değişebilmektedir. Rast gele ya da keyfi bir ÇKKV seçimi KV açısından uygun olamayan en iyi alternatifi seçmek anlamına gelebilir. Bu kararın uygunluğunu "tartışma"ya açmakta fayda vardır. Alternatifler arasından uygun olan bir ÇKKV yönteminin seçimi performans sonuçları bağlamında bu çalışmada tartışılacaktır.

Finansal performansın çok kriterli doğası ölçümlerde ÇKKV yöntemlerinin kullanılmasını gerekli kılmaktadır. Çünkü her firma aynı anda pek çok kriter için en iyisine ulaşmak ister. Bazı kriterler için maliyet minimizasyonu gerekirken bazıları için fayda maksimizasyonu gerekebilmektedir. Aşağıda örnekleri verilen ÇKKV ile FP değerlendirme çalışmaları genel olarak 2000'li yılların başında başlamış ve hızla sayısı artmaktadır. Aşağıda yaklaşık 20 yıllık klasik literatür, söz konusu ÇKKV yöntem seçimi tartışması bağlamında incelenmiştir.

Illk çalışmalardan biri olarak örnek gösterilebilecek Feng ve Wang (2000) tarafından beş farklı havayolu firmasının performansı, TOPSIS yöntemi kullanılarak değerlendirilmiştir. Performans değerlendirmede şirketlerin finansal tablolarından elde edilen 20 rasyo verisi kullanılmıştır. Çalışmada birbirine benzer sonuç veren finansal rasyoların tekrar kullanılmaması amacı ile gri ilişkisel analiz yapılmış, firma sıralamasında ise TOPSIS yöntemi kullanılmış ve finansal rasyolar ile alternatiflerin çok olduğu karmaşık karar verme yöntemlerinde TOPSIS yönteminin bir çözüm olacağı sonucuna varılmıştır. Benzer bir yaklaşımla Bayrakdaroğlu ve Yalçın (2012) tarafından BIST 30 endeksi içinde yer alan 17 adet imalat sanayi işletmesinin 1998-2011 yılları arasındaki 14 yılık bir dönem ele alınarak stratejik finansal performans değerlendirmesi yapılmıştır. Çalışmada, 7 adet değer tabanlı rasyo kullanılarak, 17 adet sanayi işletmesinin finansal performansı çok kriterli karar verme tekniklerinden, bulanık AHP ve VIKOR yöntemi ile değerlendirilmiştir. Çalışma sonucunda 17 adet sanayi işletmesi, araştırmanın yapılmış olduğu her bir yıla ait ve araştırma dönemini kapsayan ortalama finansal performans ölçütleri dikkate alınarak VIKOR yöntemi ile sıralanmıştır. Yine aynı yaklaşımla Özçelik ve Kandemir (2015) tarafından BIST’te işlem gören turizm sektöründe yer alan 7 adet firmanın 2010-2014 dönemine ilişkin finansal performansı likidite, kaldıraç, kârılık ve faaliyet göstergeleri ile ilgili 8 adet finansal rasyo kullanılarak TOPSIS yöntemi ile değerlendirilmiştir. Javadın, vd. (2016) tarafından COPRAS yöntemi ile otomotiv sektöründe faaliyet gösteren Tahran Borsasına kayıtlı olan 14 firmanın finansal performans değerlendirmesi yapılmıştır. Çalışma 2002-2011 dönemini kapsamakta olup, sekiz adet rasyo kullanılmıştır ve kriterlerin ağırlıklarını hesaplamak için bulanık AHP kullanılmış ve firmalar finansal performanslarına göre COPRAS yöntemi ile sıralanmıştır. Şit, vd. (2017) tarafından BIST Ana Metal Endeksinde yer alan 16 adet firmanın finansal performansının değerlendirilmesi TOPSIS yöntemi kullanılarak yapılmıştır. Yapılan çalışmada, firmaların 20112015 dönemleri ele alınarak 11 adet rasyo kullanılmıştır. Çalışma sonucunda söz konusu firmaların, finansal performanslarının farklılık gösterdiği ve 2011-2015 dönemleri arasında finansal performanslarında değişkenlik olduğu tespiti yer almaktadır. Kayahan Karakul ve Özaydın (2019) tarafından TOPSIS ve VIKOR yöntemleri kullanılarak BIST'de işlem gören ve 
elektrik sektöründe faaliyet gösteren sekiz adet firmanın finansal performansının değerlendirilmesi amacı ile yapılmış olan çalışmada, yedi adet finansal rasyo kullanılmış ve firmalar her iki yönteme göre finansal performanslarına göre sıralanmıştır. Ban vd. (2020) tarafından imalat sektöründe faaliyet gösteren 33 firmanın finansal performanslarını değerlendirmek amacı ile TOPSIS yöntemi kullanılarak yapılan çalışmada, sekiz adet rasyo kullanılmış ve bu rasyolardan 4'ü değer 4'ü ise muhasebe tabanlı kriterlerden oluşmaktadır. Çalışma 2011 ve 2015 yıları arasını kapsayan 5 yıllık bir dönemi kapsamakta olup firmalar finansal performanslarına göre hiyerarşik olarak sıralanmıştır. Hoe vd. (2020) tarafından Malezya'da gıda sektöründe faaliyet gösteren firmaların finansal performansı TOPSIS yöntemi ile değerlendirilmiş ve çalışma sonucunda firmalar finansal performanslarına göre sıralanmıştır. Çalışmada dört firmanın 2013-2017 yılarını kapsayan 5 dönem finansal verileri ele alınarak yedi adet rasyo kullanılmıştır.

Özetle 2000'li yıllarda başlayan ÇKKV ile FP ölçüm çalışmalarında dikkat çeken sonuçlar şöyle sıralanabilir (De Almeida-Filyo vd., 2020: 16): Çalışmalarda ÇKKV yöntemlerinin kullanım sayısı sürekli artmıştır. Diğer taraftan AHP ve TOPSIS performans çalışmalarında analiz için en çok benimsenen iki yöntemdir. Finansal modellemede en yaygın benimsenen kriterler "kârlılık" ve "risk" bazlı olmuştur. Genel anlamda finansal performans, finans alanında ÇKKV bazlı en çok çalışılan konulardan biridir. Dikkat çekici bir şekilde ÇKKV ile FP ölçüm çalışmaları daha çok yöneylem araştırması ve bilgisayar bilimleri gibi alan dergilerinde yayınlanmıştır. Son olarak ÇKKV türlerinin sıralama sonuçları genelde benzer sonuçlar (korelasyonlar) vermiştir. $\mathrm{Bu}$ durum, ÇKKV yöntemlerinin aynı olduğu veya aynı birinci alternatifi ürettiği anlamına gelmemektedir.

Yukarıda örnekleri verilen literütür ve kapsamlı özet sonuçlarından elde edilen bulgulara göre seçilen ÇKKV yönteminin neden seçildiği ile ilgili herhangi bir objektif bulguya ulaşılamamıştır. Genelde matematiksel yetenek ve kapasite düzeyi iyi olarak bilinen bazı popüler ÇKKV yöntemlerinin (TOPSIS, AHP, PROMETHEE vb.) daha çok benimsendiği söylenebilir. Kısaca alternatif ÇKKV yöntemleri arasından hangisinin seçilmesinin daha uygun olduğu ile ilgili doğrudan, net ve objektif bir çözüm yoktur. Çoğu zaman yöntem bilimciler açısından problemin cevabı ya sübjektiftir ya da yoktur denilebilir (Triantaphyllou, 2000: 199265).

\section{2. ÇKKV ile Ölçülen Finansal Performans ve Hisse Getirisi Arasındaki İlişki}

Yukarıda ele alınan literatürden de anlaşılacağı üzere ÇKKV yöntemlerinin doğrudan sonuç bağlamında karşılaştırılması ve buna göre en iyi/uygun yöntemin seçilmesi tartışmalı, zorlu olduğundan ve özellikle referans bir kıyaslama ölçütü eksikliğinden dolayı çözümsüz gibidir. Çünkü yöntemlerin ürettikleri sıralama ve en iyi alternatif belli olduğu halde, yarattığı değer tam olarak belli değildir. Yöntemlerin birbiriyle olan korelasyon katsayıları benzerlik derecelerini ortaya koysa da hangi yöntemin daha uygun olduğunu ortaya koymaz. Benzer mantıkla yaklaşılırsa bazı ÇKKV yöntemlerinin bileşkesi veya ortalamasını almak da bizi aynı sonuçsuzluğa götürecektir. Çünkü karşılaştırılabilirlik için önerilen ortak referans bir değer yoktur. Doğrudan karşılaştırmanın mümkün olmadığı böylesi bir durum için harici dolaylı bir ölçüt üzerinden karşılaştırma tatmin edici bir çözüm olabilir. Farklı ÇKKV sıralamalarının ortak ilişki noktası olan bağımsız bir aktüel sıralamanın varlığı çözümü kolaylaştırabilir. Buradaki referans alınan harici sıralama birey, uzman, grup tarafından veya yapay bir biçimde elde edilmiş değildir. Bu bağımsız sıralama hisse senedi getirisi (HG) örneğinde olduğu gibi onlarca faktörden etkilenmesine rağmen gerçek yaşamdan tekil bir sıralamadır. Aşağıda bazılarına 
değinilen literatürdeki az sayıdaki çalışmada ÇKKV ile ölçülen FP'nin HG ile arasındaki ilişki, genelde yatırım bazlı bir yaklaşımla araştırılmıştır. Çünkü iki değişken arasında belli bir ölçüde ilişki beklenir. Fakat bu çalışmada konu farklı bir bakış açısıyla ele alınmaktadır. HG bu çalışmada geçmişteki çalışmalar gibi yatırım boyutuyla değil ÇKKV'leri kıyaslamak için "objektif" bir kıyaslama ölçütü olarak ele alınır. Burada ÇKKV yöntemleri ile ölçülen FP sıralamalarının hangisinin HG ile korelasyonu daha güçlü sağladığı araştırılacaktır. Aşağıda ÇKKV ile ölçülen FP'nin HG ile arasındaki ilişki çalışmalarından bazı örneklere yer verilmiştir.

ÇKKV ve HG ölçütü ilişkisi ile ilgili literatürün ilk örneklerinden biri Özden vd. (2012)’nin çalışmasıdır. Çimento sektöründe faaliyet gösteren firmaların finansal performansları açısından sıralanması amacı ile VIKOR yöntemi kullanılarak yapılan çalışmada, söz konusu sektörde faaliyet gösteren firmaların 2011 yılı finansal göstergeleri kullanılmıştır. Çalışmada kullanılan kriterlerin ağırlık katsayıları piyasada uzman olan kişilere anket yapılarak tespit edilmiştir. Çimento sektöründeki firmalar VIKOR yöntemi kullanılarak finansal performanslarına göre sıralanmış ve sıralama ile pay senetleri getirisi arasında bir ilişki olup olmadığı sıra korelasyon katsayısı ile incelenmiştir. Buna göre sıralamalar arasında tüm baz yılları temsil eden sürdürülebilir bir ilişkinin olmadığı söylenebilir. Sakarya ve Yıldırım (2016) tarafından BIST'de yer alan 14 enerji firmasının finansal performansı ile pay senedi getirileri arasındaki ilişkiyi incelemek amacı ile yapılan çalışmada, 14 adet rasyo kullanılmıştır. Hesaplanan rasyolar, firmaların performanslarını gösteren TOPSIS puanlarına dönüştürülmüştür. Bu puanlar ile şirketlerin yıllık ortalama getirileri arasındaki ilişkinin araştırılmasında ise panel veri analizi kullanılmıştır. Çalışma sonucunda TOPSIS sıralaması ile pay senetlerinin getirileri arasında kısa dönemli bir eş-bütünleşme olduğu fakat sıralama ile pay senedi getirileri arasında karşılıklı bir nedensellik ilişkisi tespit edilememiştir. Yine başka bir çalışmada Şahin ve Sarı (2019) BIST İmalat sektöründeki firmaların finansal performans sıralamalarının belirlenmesi amacıyla entropy bazlı TOPSis ve ViKOR yöntemlerini kullanmışlardır. Ayrıca HG sıralamaları ile FP sıralamaları arasındaki ilişki spearman korelasyon analizi ile incelenmiştir. Çalışmada hisse senedi getirisi ile finansal performans arasında yıllar itibariyle sürdürülebilir anlamlı bir ilişkinin olmadığı sonucuna varılmıştır. Diğer taraftan uluslararası literatürde iki değişken arasında tek dönemlik anlamlı ilişki bulan bazı yazarlar (Yaakob vd., 2017) vardır. Çalışmada her ne kadar HG ile TOPSIS türlerini kıyaslamış olsalar da bunu farklı ÇKKV'leri kıyaslamak için kullanmamışlardır.

Özetle çalışmalarda söz konusu iki değişken arasında tüm baz dönemler için sürdürülebilir istatistiki bir ilişki olmadığı için sonraki aşama olan ÇKKV seçimi mümkün değildir. Yani istatistiksel olarak anlamlı ve sürdürülebilir korelasyonların eksikliği ÇKKV'leri karşılaştırmaya gerek bırakmamıştır denebilir. Optimal çözümlerin bilinemediği bu tür çalışmalarda pareto optimal uzlaşmacı çözümler öneren ÇKKV yöntemlerinin sonuç bazlı olarak karşılaştırılması için doğrudan bir ölçüt hali hazırda mevcut değildir. Bu durumda dolaylı çözümler tatmin edici olabilir. Bu doğrultuda finansal performans ile hisse getirisi arasındaki istatistiki ilişkinin ÇKKV'leri karşılaştırmada objektif bir dolaylı ölçüt olarak kullanımı tartışılması gereken önemli bir yaklaşımdır. Çalışmada önerilen bu yaklaşım sermaye piyasasında test edilecektir. 


\section{Araştırmanın Yöntemi}

\subsection{Kullanılan Performans Ölçütleri ve Seçim Sorunları}

Finansal performans göstergeleri daha çok likidite, faaliyet, karlılık ve borsa performans oranları ile kategorize edilmektedir. Performans göstergesi olarak MVA, EVA gibi bilinen klasik değer tabanlı göstergelerin yanında Altman-Z gibi bir firmanın hem risk ve hem de başarısını çok iyi bir şekilde ortaya koyan başka göstergeler de kullanılmaktadır. Firmayla ilgili tüm tarafları tatmin edecek ortak bir amaç bulmak finansal performans hesaplamasında önemlidir. Kar ve PD (piyasa değeri) maksimizasyonu firmaların nihai amaçlarıdır. Özellikle kar ve hissedar değerine odaklı bir finansal performans ölçümünde göstergelerin rastgele seçilmemesi ve ÇKKV teorisine de uygun olması gerekmektedir. Örneğin FP göstergeleri arasında cari oran için 2, likidite oranı 1, nakit oranı 0,2 ve özkaynak/yabancı kaynak için 1 olarak önerilen ideal değerler vardır (Çabuk ve Lazol, 2005: 190-196). Faydanın maksimizasyonu ve maliyetin minimizasyonu varsayımıyla işletilen ÇKKV prosedürü için söz konusu oranlar doğrudan ÇKKV mimarisinde kullanılamaz. Diğer taraftan sıfır stok ve sıfır ticari alacak politikası ile çalışan bazı firmaların bir kısım faaliyet oranlarının hesaplanması oldukça mantıksız ve problemli olabilir. Dahası FP ile HG arasındaki ilişkiyi istatistiksel olarak yani anlamlı olarak sağlayan gösterge sayısı çok olmayabilir. Borsanın ve yatııımının benimsediği değer yaratan yaygın oranların kullanımı bu açıdan kritik önemdedir. Diğer taraftan birbiriyle amaç olarak aynı ve oldukça benzer sonuçlar veren göstergelerin kullanımına da dikkat etmek gerekecektir. Son olarak ÇKKV çalışmaları için (HG dönemsel ve fiyat bazlı değişimsel olarak hesaplandığı için) FP göstergelerinin dönemsel ve değişimsel hesaplanması önerilebilir. Çalışmalar, farklı amaçlarla ağırlıklı olarak statik gösterge kullanırken bu çalışmada yaygın bilinen göstergelerin dinamik (değişimsel) formu kullanılacaktır. İstatistiksel olarak FP ile HG değişkenleri arasında anlamlı bir ilişki olduğunda bir sonraki aşamaya geçilecek ve ÇKKV'leri karşılaştırabilmek daha mümkün hale gelecektir. Değinilen tüm bu gerekçelerin ışığında bu çalışmada ÇKKV ile finansal performans değerlendirmesi yapabilmek için dört yaygın performans ölçütü seçilmiştir: Tümü büyüme (değişimsel) bazlı olarak bunlar Altman-Z score, ROE, ROA, PD/DD göstergeleridir. Sınıflandırmak gerekirse kullanılan göstergelerin bir firmanın karlılık verimi, firma riski ve üretilen değeri doğrudan temsil ettiği söylenebilir. Daha önceki pek çok çalışmadan farklı olarak burada firma riski de önemsenmektedir. Altman-Z skoru risk ve belirsizliğe karşı ÇKKV çalışmalarında bir finansal gösterge olarak kullanılmaktadır.

Tablo 1: Çalışmada Kullanılan Performans Ölçütleri, Ağırıklandırma ve ÇKKV Yöntemleri

\begin{tabular}{c|c|c}
\hline Ağırıılandırma Yöntemi & ÇKKV Yöntemi & Performans Kriterleri \\
\hline & TOPSIS, LINMAP, & $\Delta$ ROE, $\Delta$ ROA (karlıık verimi) \\
Eşit Ağırlıklandırma (Mean Weight) & WSA, SAW & $\Delta$ Altman-Z Skoru (risk) \\
& & $\Delta$ PD/DD (üretilen değer) \\
\hline
\end{tabular}

(1) Altman-Z Skoru

Finansal performans uygulamalarında bu ölçüt özellikle firma başarısızlık performansını değerlendirmek için klasik ve sık kullanılan bir ölçüttür. Bu oranın değişimini ifade eden Altman-Z skor büyümesi bazılarına göre aynı zamanda hissedar değerini de en iyi temsil eden göstergedir (Carton, 2004: 281). Altman-Z score başarı, başarısızlık, risk derecesi ile hisse getirisi ilişkisini ayna anda sağlayabilen, kritik boyutlara sahip bir göstergedir. Ayrıca fayda yönlü bir kriter olduğundan bu göstergede her zaman daha yüksek değerler arzu edilir. 
(2) $R O E$

Net karın özkaynaklara oranı olarak tanımlanan ROE, finansal performansı değerlendirmek için önerilen klasik ve başarılı bir ölçüttür. Karın verimliliğini özsermayeye göre ölçer (Bodie vd., 2018: 451): Net Kar/Özsermaye oranı ile ifade edilir.

(3) $R O A$

ROA Varlıkların ne kadar verimli kullanıldığının bir göstergesidir. Finansal performansı değerlendirmek için yaygın kullanılan bir ölçüttür. Karın verimliliğini varlıklara göre ölçer (Bodie vd., 2018: 450): ROA= Net Kar) / Toplam Varlıklar oranı ile ifade edilir. ROE'ye göre fazladan firmanın borçluluk riskini de yansıtır.

(4) $P D / D D$

Piyasa değerinin özsermayeye oranlanmasıdır. Defter değerinin karşılığında üretilen piyasa değeridir (Stewart, 2013: 118). Özsermayenin piyasada fiyatlanması sonucu bir bakıma yaratılan ya da aşınan değeri ortaya koyar. PD/DD = Piyasa Değeri/Özsermaye oranı ile ifade edilir.

Bazı çalışmalar istatistiksel olarak pozitif FP değişiminin pozitif HG (yani fiyat değişimi yüzdesi) sağlaması gerektiğini ileri sürmektedir. Bu çalışmalar dinamik ölçütlerin statik ölçütlere alternatif olarak ya da birlikte kullanılabileceğini önermiştir (Carton ve Hofer 2006: 235). Dinamik, büyüme ya da değişim göstergesi "rasyonun baz döneme göre değişimi" olarak tarif edilen durumdur. Büyüme ya da değişim bazlı oranlar şöyle hesaplanabilir:

$\Delta$ Rasyo $=$ Rasyo(t, baz dönem sonrası) - Rasyo(t-1,baz dönem) .

Bu çalışmada da değişim oranları kullanılmıştır. Aşağıda Tablo 2'de çalışmada kullanılan oranlar (kriterler), hisse senedi getirisi ve nasıl hesaplandıkları toplu olarak yer almaktadır.

Tablo 2: Çalışmada Kullanılan Değişkenlerin Hesaplanması

\begin{tabular}{|c|c|c|}
\hline Oranlar & Hesaplanması & Referanslar \\
\hline$P D / D D$ & PD/ÖZSERMAYE & Stewart (2013) \\
\hline$R O E$ & Net Kar /Özkaynak Değeri & Bodie vd. (2018) \\
\hline$R O A$ & Net Kar / Aktifler & Bodie vd. (2018) \\
\hline ALTMAN-Z Skor & $\begin{array}{l}\text { 1.2A + 1.4B + 3.3C + 0.6D + 1.0E } \\
\mathrm{A}=\text { Çalışma Sermayesi/Toplam Varlıklar } \\
\mathrm{B}=\text { Dağıtılmamıs Karlar/Toplam Varlıklar } \\
\mathrm{C}=\text { Faiz ve Vergi Öncesi Kazanç/Toplam Varlıklar } \\
\mathrm{D}=\text { Varlıkların Piyasa Değeri/Toplam Borçlar } \\
\mathrm{E}=\text { Satışlar/Toplam Varlıklar }\end{array}$ & Carton, (2004) \\
\hline Hisse Senedi Getirisi & $\begin{array}{l}\text { (Hissenin Cari Fiyatı - Önceki Dönem Baz Fiyat) / Baz Fiyat } \\
\text { (5) }\end{array}$ & Carton ve Hofer (2006) \\
\hline
\end{tabular}

Bu çalışmada amaç odaksız çok sayıda kriter kullanmak yerine hissedar değeri yarattığı bilinen ya da tahmin edilen az sayıda kriter kullanımı yeğlenmiştir. Bu kriterler kar verimliliği, risk ve değer üretimini yansıtan genel kabul görmüş temsili kriterlerdir. 


\section{2. ÇKKV Yöntemleri}

Uygun bir ÇKKV yöntemini daha objektif olarak seçebilmek, seçimde keyfilikten kaçınmak ve dolayısıyla bu çalışmanın gereği olarak bir "ölçüt" elde etmek için bu çalışmada iki adet yaygın kullanılan ÇKKV yöntemi ürettikleri spesifik bir somut değere göre karşılaştırılacaktır. ÇKKV yöntemleriyle ilgili teorik bilgilere aşağıda değinilmiştir.

Çalışmada seçilen yöntemlerden ilki olan TOPSIS, vektörel normalizasyon, ideal değerlere öklidyen uzaklık varsayımlarıyla sıralama üretiminde özgünleşmektedir. TOPSIS'e göre en iyi alternatif aynı anda ideal pozitife en yakın ve ideal negatife en uzak olandır. SAW'da ise normalizasyon dışında herhangi bir varsayım ya da sınırlama yoktur. Basit toplamlı fayda esasına göre çalışır.

ideal Çözüme Benzerlik ile Tercih Sırasına Ulaşma Tekniği (TOPSIS)

Hwang ve Yoon tarafından geliştirilen "Ideal Çözüme Benzerlik Yolu ile Tercih Sırasına Ulaşma Tekniği" (Technique for Order Preference by Similarity to Ideal Solution TOPSIS) ideal alternatife göreli yakınlığı en fazla olan alternatifi seçme mantığına dayalıdır. Bu yöntemde seçilen alternatif aynı anda hem pozitif ideal çözüme en yakın olan hem de negatif ideal çözüme en uzak olandır (Çınar, 2004: 133).

Yöntemin adımları ve formüller şöyledir (Wang ve Rangaiah, 2017: 561):

Adım 1: Karar Matrisinin Oluşturulması

$$
F_{i j}=\frac{f_{i j}}{\sqrt{\sum_{i=1}^{m} f_{i j}^{2}}}
$$

Adım 2: Normalize Edilmiş Karar Matrisinin Oluşturulması

$$
v_{i j}=F_{i j} \times w_{j}
$$

Adım 3: Ağırıklandırılmış normalize matrisin elde edilmesi

$$
\begin{aligned}
A^{+} & =\left\{\left(\operatorname{Max}_{i}\left(v_{i j}\right) \mid j \in J\right),\left(\operatorname{Min}_{i}\left(v_{i j}\right) \mid j \in J^{\prime}\right) \mid i \in 1,2, \ldots, m\right\} \\
& =\left\{v_{1}^{+}, v_{2}^{+}, v_{3}^{+}, \ldots, v_{j}^{+}, \ldots, v_{n}^{+}\right\}
\end{aligned}
$$

Adım 4: ideal çözümlerin bulunması

$$
\begin{aligned}
A^{-} & =\left\{\left(\operatorname{Min}_{i}\left(v_{i j}\right) \mid j \in J\right),\left(\operatorname{Max}_{i}\left(v_{i j}\right) \mid j \in J^{\prime}\right) \mid i \in 1,2, \ldots, m\right\} \\
& =\left\{v_{1}^{-}, v_{2}^{-}, v_{3}^{-}, \ldots, v_{j}^{-}, \ldots, v_{n}^{-}\right\}
\end{aligned}
$$

Adım 5: Uzaklık Değerlerinin (Ayırma Ölçüsünün) Hesaplanması

$$
S_{i+}=\sqrt{\sum_{j=1}^{n}\left(v_{i j}-v_{j}^{+}\right)^{2}} \quad i=1,2,3, \ldots, m
$$

Adım 6: Ideal Çözüme olan Göreli Yakınlığın Hesaplanması

$$
S_{i-}=\sqrt{\sum_{j=1}^{n}\left(v_{i j}-v_{j}^{-}\right)^{2}} \quad i=1,2,3, \ldots, m
$$

Adım 7: Tercih Derecelendirilmesinin Yapılması (Alternatiflerin Sıralanması)

$C_{i}=\frac{S_{i-}}{S_{i-}+S_{i+}}$

Çok Boyutlu Tercih Analizi İçin Doğrusal Programlama Tekniği (LINMAP)

LINMAP, TOPSIS ile benzer ilkeyi paylaşır, ancak ikincisi, pozitif ve negatif ideal noktalara olan mesafelerin hesaplanmasını içerirken, birincisi yalnızca pozitif ideale olan mesafeyi 
dikkate alır. Yukarıda gösterilen TOPSIS'deki ilk 5 adım LINMAP'ı ifade eder. Önerilen çözüm yani en iyi olan alternatif, en büyük Si+'ya sahip olandır (Wang ve Rangaiah, 2017: 562).

\section{Basit Toplamlı Ağırıklandırma (SAW):}

SAW, her bir optimal çözümün skoru, yani objektif matristeki satır (i), normalize edilmiş hedef (j) ve ağırlığının (wj) çarpımı ile elde edilir. Seçilen çözüm, en yüksek puana sahip olandır. Yöntem şu iki aşamadan oluşmaktadır (Wang ve Rangaiah, 2017: 561-564):

Adım 1. Objektif matris $m$ satır ve $n$ sütunlu oluşturulur. Veriler normalize edilir.

$$
\begin{aligned}
& F_{i j}=\frac{f_{i j}}{f_{j}^{+}} \text {buradaki } f_{j}^{+}=\operatorname{Max} x_{i \in m} f_{i j} \text { fayda yönlü olan maksimizasyon kriterini, } \\
& F_{i j}=\frac{f_{j}^{-}}{f_{i j}} \text { buradaki } f_{j}^{-}=\operatorname{Min} n_{i \in m} f_{i j} \text { maliyet yönlü olan minimizasyon kriterini } \\
& \text { göstermektedir. }
\end{aligned}
$$

Adım 2. Ağırlıklı normalleştirilmiş objektif matris elde edilir.

$v_{i j}=F_{i j \times w_{j}}$

Adım 3. Her alternatif için ağırlıklı değerlerin toplamı bulunur.

$A_{i}=\sum_{j=1}^{n} v_{i j}$

Adım 4. En yüksek puana sahip olan alternatif ( $\mathrm{Ai}$ ) önerilen en uygun çözümdür. Bundan sonra artık alternatifler fayda değerlerine göre sıralanabilir. Karar verme probleminin en uygun çözümü en yüksek fayda değerine sahip alternatiftir.

Ağırlıklı Toplam Yaklaşımı (WSA):

WSA, SAW ile benzer ilkeyi paylaşır, ancak ikincisi maksimum doğrusal normalizasyon kullanırken WSA minimum-maksimum doğrusal normalizasyon kullanmaktadır (Şen, 2014: 58). Kısaca WSA ile SAW yöntemlerinin normalizasyon dışındaki adımları aynıdır ve yukarıda SAW yönteminde bu adımlar gösterilmiştir. Aşağıda WSA'nın SAW yönteminden tek farkı olan ve literatürde max-min olarak ifade edilen normalizasyon türünün formülü (birincisi fayda yönlü ve ikincisi maliyet yönlü kriterler için olmak üzere) ayrıca gösterilmiştir (Wang ve Rangaiah, 2017:562):

$$
\begin{aligned}
F_{i j} & =\frac{f_{i j}-\min _{i \in m} f_{i j}}{\max _{i \in m} f_{i j}-\min _{i \in m} f_{i j}} \\
F_{i j} & =\frac{\max _{i \in m} f_{i j}-f_{i j}}{\max _{i \in m} f_{i j}-\min _{i \in m} f_{i j}}
\end{aligned}
$$

\subsection{Ağırlıklandırma Yöntemi}

Ağırıklandırma yöntemi en iyi alternatifi seçerken ve sıralamayı etkileme bakımından esasen kritik bir ÇKKV aşamasıdır. Bu çalışmanın odak noktasına uygun olarak ÇKKV'ler referans değer (HG) ile ürettikleri korelasyon katsayısına göre karşılaştırılacağı için sabitlendirilmiş tek bir ağırlıklandırma yöntemi ile yetinilmiştir. Burada ağırlıklandırma yöntemi olarak yaygın kullanılan eşit ağırlıklandırma yöntemi tercih edilmiştir. Eşit ağırlıklandırmanın diğer ağırlıklandırma yöntemlerine göre ağırlıkların göreceli önemiyle ilgili olarak daha yargısız bir teknik olduğu söylenebilir. 


\section{Eşit Ağırlıklandırma Tekniği (Mean Weight Method)}

Alternatiflerin performansları kıyaslanırken kullanılan tüm kriterlerin eşit öneme sahip olduğu varsayımıyla kriterlerin eşit ağırlıklandırılmasını baz alan bir tekniktir. Kriterlerin önem derecesinin belirlenmesinde yeterli bilgiye ve uzman görüşüne sahip olunmadığı durumlarda bu teknik kullanılabilir. Klasik ve yaygın kullanılan bir tekniktir. ÇKKV yöntemlerinin ne derece önemli rol oynadığını görebilmek amacıyla eşit ağırlıklandırma yöntemi kontrol grubu gibi düşünülerek diğer ÇKKV yöntemleri ile elde edilen sonuçlar arasındaki farklılık ortaya konabilir (Şen, 2014: 77).

\section{Uygulama}

Bu bölümde, finansal performans ölçümünde kullanılan ÇKKV tabanlı yöntemlerin hesaplama sonuçları değerlendirilmektedir. Öncelikle veri seti ve uygulama süreciyle ilgili açıklamalara yer verilecektir.

\subsection{Deneysel Tasarım (Ya da Veri Seti)}

Finansal performansın ÇKKV yöntemleriyle ölçülebilmesi için Türkiye'de BIST imalat-metal eşya alt sektörüne kayıtlı faaliyet gösteren, verilerine ulaşılabilir 25 adet firma çalışmaya dahil edilmiştir. Bu firmalara ait dört farklı performans göstergesi ise karar kriteri olarak belirlenmiştir. Çalışma 2015-2019 yılları arasındaki birer yıllık zaman kesitlerinden oluşmaktadır. Her bir zaman kesiti için firmaların finansal performansları hesaplanacaktır. Firmaların finansal performans göstergeleri ve hisse senedi getirilerinin elde edilmesi için ticari bir yazılım olan FINNET veri yazılımından yararlanılmıştır. Performans ölçümü için ÇKKV metodu olarak TOPSIS, LINMAP, WSA ve SAW metodları kullanılacaktır. Ardından ÇKKV sonuçları HG sıralamaları ile karşılaştırılarak her dönem için Spearman sıra korelasyon katsayıları elde edilecektir. Sonuçlara göre daha yüksek korelasyon katsayısı üreten ÇKKV metodu daha uygun ÇKKV metodu olarak değerlendirilebilecektir.

Çalışmanın deneysel sürecinin adımları şöyle açıklanabilir: Adım 1, kriterlerin belirlenmesi ve ilk karar matrisini hazırlama aşamasıdır. Elde edilen karar kriteri değerleri ile TOPSIS ve SAW yöntemleriyle finansal performans sonuçlarını hesaplayabilmek için her yıl için ayrı bir şekilde karar matrisine yerleştirilmiştir. Adım 2, ÇKKV yöntemleri ile FP ölçümü aşamasıdır. 5 dönem bazında 25 firmanın TOPSIS ve SAW işlem hesaplamalarını yapabilmek amacıyla Excel programı kullanılmıştır. Adım 3, FP-HG iliş̧kisini ortaya koyma aşamasıdır. Elde edilen ÇKKV sıralama sonuçlarına anlam katabilmek ve değerlendirebilmek için HG bir referans kontrol aracı olarak kullanılmıştır. ÇKKV sıralamaları ile aynı zaman kesitinde oluşan dönemsel hisse getirisi sıralamaları arasındaki ilişkiden yola çıkılarak ÇKKV'ler arasında hangisinin daha üstün sonuçlar verebileceğini tespit etmek için spearman korelasyon analizi yapılmıştır. Korelasyon analizleri Minitab programında yapılmıştır. Başka bir ifadeyle ÇKKV'lerin ürettiği korelasyon (Rho) katsayısına göre iki ÇKKV metodu karşılaştırılmıştır. Böylece gerçek bir yaşam sıralaması olan HG'yi hangi yöntemin daha iyi modellediği objektif ve dolaylı bir ölçüt üzerinden ortaya konmuş olacaktır. Aşağıda şekil 1'de finansal performansın ölçümü ve HG ile ilişkisinin detayları yani çalışmanın deneysel sürecinin adımları gösterilmiştir. 
Şekil 1: Çalışmanın Akış Diyagramı

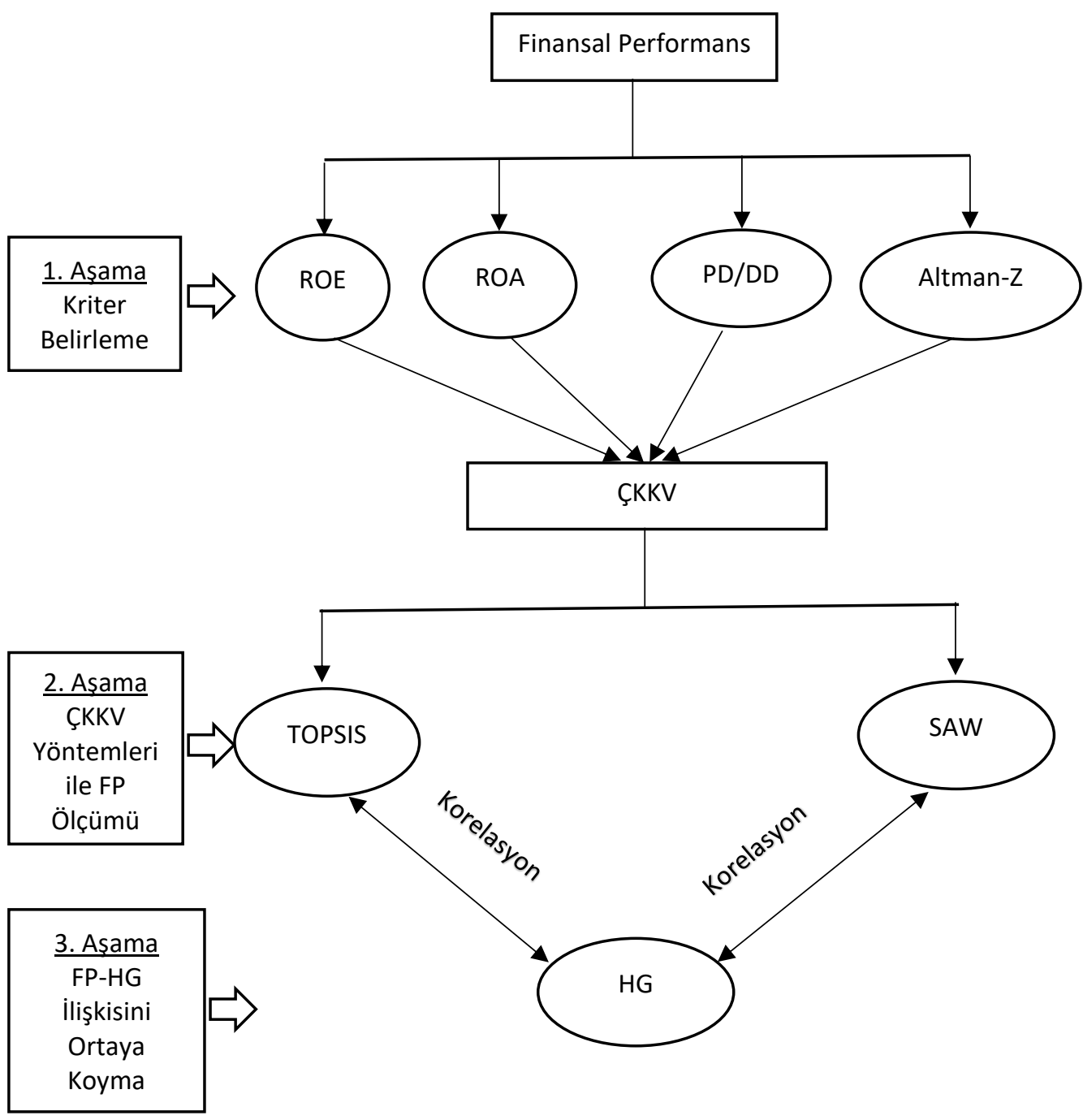

\subsection{Bulgular}

Çalışmada kullanılan ilk karar matrisleri yani performans kriterlerinin verisi her baz dönem için ayrı ayrı olmak üzere aşağıdaki tablolarda sunulmuştur. Aşağıdaki tablo 3'de 2015 ve 2019 dönemlerinde firmaların finansal performansının hesaplanabilmesi için gereken performans göstergelerinin (karar kriterlerinin) değerleri verilmiştir. Her bir yılın değerleri o yılın karar matrisini oluşturmak için kullanılmaktadır. Her bir yıl için $4 \times 25^{\prime}$ lik boyutta toplam 5 adet matris hazırlanmıştır. Bilindiği gibi ÇKKV mimarisinde ham veriler ilk karar matrisine yer almaktadır. Aşağıdaki tablolarda ilk karar matrisi için gereken firmaların finansal performans göstergeleri HG değerleri ile birlikte gösterilmiştir. Böylece firmaların hem içsel finansal performansı ve hem de dışsal piyasa performansları beraber görülebilmektedir. Tüm çalışmalarda olduğu gibi burada da finansal değerlerin oran şeklinde ve birimsiz olması dikkat çekmektedir. 
Eskişehir Osmangazi Üniversitesi İktisadi ve İdari Bilimler Fakültesi Dergisi

Tablo 3: Karar Matrisi İçin Gereken Değerler ve HG (2015 Yılı)

\begin{tabular}{|c|c|c|c|c|c|}
\hline \multicolumn{6}{|c|}{2015 Yılı } \\
\hline & $H G$ & ROA & ROE & PD/DD & Altman-Z \\
\hline ALCAR & $-0,04274$ & 0,02 & 0,02 & $-0,11$ & $-0,79$ \\
\hline ARCLK & $-0,06867$ & 0,01 & 0,04 & $-0,3$ & $-0,15$ \\
\hline ASUZU & $-0,23897$ & $-0,03$ & $-0,05$ & $-0,38$ & $-0,63$ \\
\hline AYES & $-0,17$ & 0,03 & 0,03 & $-0,1$ & $-0,24$ \\
\hline BFREN & 0,15917 & 0,07 & 0,07 & 0,91 & 4,23 \\
\hline DITAS & $-0,34591$ & $-0,15$ & $-0,26$ & $-0,58$ & $-2,94$ \\
\hline EGEEN & 0,567082 & 0,01 & 0,08 & 0,19 & $-6,62$ \\
\hline EMKEL & $-0,07194$ & $-0,01$ & 0,01 & $-0,06$ & $-0,21$ \\
\hline FMIZP & $-0,02848$ & 0,1 & 0,11 & $-1,44$ & 3 \\
\hline FROTO & $-0,06974$ & 0,02 & 0,06 & $-0,68$ & 0,19 \\
\hline GEREL & 1,310606 & 0,16 & 0,23 & 0,71 & 2,12 \\
\hline IHEVA & $-0,16667$ & 0 & 0 & $-0,08$ & $-0,23$ \\
\hline JANTS & $-0,39553$ & $-0,11$ & $-0,16$ & $-1,26$ & $-2,44$ \\
\hline KARSN & 0,041379 & 0,05 & 0,14 & $-0,06$ & 0,13 \\
\hline KATMR & 1,345845 & 0,04 & 0,09 & 1,17 & 1,25 \\
\hline KLMSN & 0,550607 & 0,02 & 0,09 & 0,23 & 0,21 \\
\hline OTKAR & 0,035159 & $-0,01$ & 0,02 & 0,27 & $-0,31$ \\
\hline PARSN & 0,461066 & $-0,02$ & $-0,02$ & 0,12 & $-1,07$ \\
\hline PRKAB & 0,888112 & 0 & 0 & 0,82 & 0,17 \\
\hline SILVR & $-0,10417$ & $-0,12$ & $-0,27$ & $-0,06$ & $-0,17$ \\
\hline TMSN & 0,749518 & 0,03 & 0,03 & 1,35 & 2,85 \\
\hline TOASO & 0,188088 & 0 & 0,06 & 0,11 & $-0,24$ \\
\hline TTRAK & $-0,09499$ & $-0,01$ & 0,02 & $-0,12$ & $-0,36$ \\
\hline VESBE & 0,035185 & 0,02 & 0,03 & $-0,13$ & $-0,15$ \\
\hline VESTL & $-0,19528$ & 0 & $-0,04$ & $-0,49$ & $-0,18$ \\
\hline
\end{tabular}

Tablo 4: Karar Matrisi İçin Gereken Değerler ve HG (2016 ve 2017 yılları)

\begin{tabular}{lccccc|ccccc}
\hline & \multicolumn{1}{c}{$\mathbf{2 0 1 6}$ Yllı } & \multicolumn{3}{c}{$\mathbf{2 0 1 7}$ Yılı } \\
\hline ALCAR & HG & ROA & ROE & PD/DD & Altman-Z & HG & ROA & ROE & PD/DD & Altman-Z \\
ARCLK & 0,517538 & 0,00 & 0,00 & 0,15 & $-0,27$ & 0,600159 & 0,02 & 0,04 & 0,61 & 1,34 \\
ASUZU & 0,091728 & $-0,07$ & $-0,08$ & 0,37 & 0,10 & 0,015094 & $-0,04$ & $-0,14$ & $-0,29$ & $-0,16$ \\
AYES & 0,626506 & 0,00 & 0,02 & 0,48 & $-0,42$ & $-0,53093$ & 0,02 & $-0,04$ & $-0,66$ & $-0,44$ \\
BFREN & $-0,17552$ & 0,05 & 0,09 & $-2,07$ & $-2,00$ & 0,401159 & $-0,01$ & 0,02 & 1,56 & $-0,59$ \\
DITAS & $-0,23077$ & $-0,05$ & $-0,15$ & $-0,14$ & $-0,60$ & 0,5175 & 0,12 & 0,39 & 0,46 & 0,64 \\
EGEEN & $-0,28581$ & $-0,07$ & $-0,27$ & $-2,17$ & $-2,91$ & 0,434938 & 0,01 & 0,03 & 0,17 & 1,47 \\
EMKEL & $-0,13178$ & 0,01 & 0,03 & $-0,16$ & 0,10 & 0,419643 & $-0,05$ & $-0,18$ & 0,28 & $-0,33$ \\
FMIZP & $-0,09837$ & 0,01 & $-0,06$ & $-0,45$ & $-13,21$ & $-0,02168$ & 0,05 & 0,10 & $-0,50$ & $-0,46$ \\
FROTO & 0,009908 & 0,00 & 0,01 & $-0,08$ & $-0,10$ & 0,970242 & 0,02 & 0,16 & 2,33 & 0,66 \\
GEREL & $-0,47541$ & $-0,19$ & $-0,71$ & $-0,78$ & $-1,34$ & 1,94375 & 0,05 & 0,11 & 1,26 & 1,22 \\
IHEVA & $-0,03333$ & $-0,05$ & $-0,07$ & 0,02 & $-0,22$ & 0,758621 & 0,00 & 0,00 & 0,23 & 0,30 \\
JANTS & 0,046351 & 0,00 & 0,01 & $-0,06$ & 0,47 & 0,524976 & 0,09 & 0,20 & 0,38 & 0,31 \\
KARSN & $-0,28477$ & $-0,02$ & $-0,10$ & $-0,66$ & $-0,27$ & 0,444444 & 0,06 & 0,41 & 0,76 & 0,61 \\
KATMR & $-0,16343$ & $-0,05$ & $-0,28$ & $-0,95$ & $-1,38$ & 0,63388 & $-0,01$ & 0,01 & 0,70 & $-0,19$ \\
KLMSN & 0,989556 & 0,02 & 0,13 & 0,55 & 0,13 & $-0,23228$ & $-0,05$ & $-0,32$ & $-0,59$ & $-0,24$ \\
OTKAR & 0,485523 & $-0,01$ & $-0,04$ & 4,39 & 0,34 & $-0,07196$ & 0,01 & 0,12 & $-2,70$ & $-0,14$ \\
PARSN & 0,169705 & $-0,03$ & $-0,06$ & 0,21 & $-0,41$ & 0,402878 & 0,02 & 0,04 & 0,35 & 0,20 \\
PRKAB & $-0,20741$ & 0,01 & 0,03 & $-0,52$ & $-0,13$ & 0,186916 & $-0,02$ & $-0,08$ & 0,07 & 0,00 \\
SILVR & 0,302326 & 0,03 & 0,07 & 0,19 & $-0,28$ & 0,955357 & 0,10 & 0,32 & 0,53 & 1,05 \\
TMSN & $-0,18392$ & 0,00 & 0,00 & $-1,17$ & $-3,19$ & 0,024291 & $-0,11$ & $-0,20$ & $-0,75$ & $-1,14$ \\
TOASO & 0,300264 & 0,00 & 0,01 & 0,50 & 0,27 & 0,340097 & 0,01 & 0,06 & 0,44 & 0,31 \\
TTRAK & 0,078361 & 0,03 & 0,20 & 0,02 & $-0,06$ & 0,013333 & $-0,05$ & $-0,11$ & $-0,37$ & $-0,39$ \\
VESBE & 0,075134 & 0,05 & 0,21 & $-0,49$ & $-0,25$ & $-0,20383$ & $-0,04$ & $-0,13$ & $-0,68$ & $-0,85$ \\
VESTL & 0,242661 & 0,01 & 0,07 & 0,08 & 0,09 & 0,192126 & $-0,01$ & $-0,08$ & $-0,05$ & $-0,39$ \\
\hline
\end{tabular}


Tablo 5: Karar Matrisi İçin Gereken Değerler ve HG (2018 ve 2019 yılları)

\begin{tabular}{lccccc|ccccc}
\hline & \multicolumn{7}{c}{$\mathbf{2 0 1 8}$ Yıll } & & & \multicolumn{3}{c}{$\mathbf{2 0 1 9}$ Yllı } \\
\hline ALCAR & HG & ROA & ROE & PD/DD & Altman-Z & HG & ROA & ROE & PD/DD & Altman-Z \\
ARCLK & $-0,26626$ & $-0,02$ & $-0,01$ & $-0,67$ & $-2,43$ & 0,52439 & $-0,06$ & $-0,08$ & 0,53 & 0,28 \\
ASUZU & $-0,32088$ & $-0,00$ & 0,01 & $-0,71$ & $-0,47$ & 0,319823 & $-0,00$ & $-0,00$ & 0,16 & 0 \\
AYES & $-0,16471$ & $-0,01$ & $-0,03$ & $-0,16$ & $-0,31$ & 0,969256 & 0,05 & 0,15 & 0,88 & 0,61 \\
BFREN & $-0,16279$ & 0,10 & 0,16 & $-1,9$ & $-1,26$ & 0,789506 & $-0,08$ & $-0,07$ & 5,08 & 2,07 \\
DITAS & $-0,0972$ & 0,02 & 0,06 & $-0,57$ & 0,29 & 0,744526 & $-0,07$ & $-0,21$ & 1,77 & $-0,1$ \\
EGEEN & 0,068323 & 0,10 & 0,48 & $-0,57$ & $-3,21$ & 0,6875 & $-0,17$ & $-0,20$ & 0,88 & 1,06 \\
EMKEL & $-0,38365$ & $-0,06$ & $-0,24$ & $-0,16$ & $-0,46$ & 0,622449 & 0,08 & 0,53 & 0,17 & 0,4 \\
FMIZP & 0,274003 & 0,10 & 0,20 & 0,11 & 13,76 & 1,891594 & $-0,056$ & $-0,02$ & 7,53 & 13,71 \\
FROTO & $-0,17012$ & 0,00 & $-0,01$ & $-1,32$ & $-0,03$ & 0,417 & $-0,00$ & $-0,01$ & 0,82 & 0,05 \\
GEREL & $-0,25053$ & $-0,05$ & $-0,11$ & $-1,03$ & $-0,61$ & $-0,09632$ & $-0,15$ & $-0,33$ & 1 & $-1,04$ \\
IHEVA & $-0,35294$ & 0,02 & 0,04 & 0,27 & 0,62 & 8,484848 & 0,06 & 0,07 & 2,44 & 7,91 \\
JANTS & $-0,14091$ & 0,00 & 0,02 & $-0,78$ & $-0,60$ & 1,097122 & 0,02 & 0,02 & 0,95 & 1,58 \\
KARSN & $-0,17949$ & $-0,01$ & $-0,07$ & 0,11 & $-0,33$ & 0,234375 & 0,01 & 0,10 & $-0,21$ & 0,44 \\
KATMR & $-0,5092$ & $-0,04$ & $-0,33$ & $-1,19$ & $-0,52$ & $-0,34583$ & 0,00 & 0,08 & 0,63 & 0,5 \\
KLMSN & $-0,32308$ & 0,04 & 0,29 & $-0,07$ & 0,20 & 4,575758 & 0,02 & 0,06 & 1,99 & 0,56 \\
OTKAR & $-0,28716$ & 0,02 & 0,17 & $-4,02$ & $-0,21$ & 0,8017 & 0,05 & 0,12 & 0,54 & 0,81 \\
PARSN & $-0,25128$ & $-0,04$ & $-0,09$ & $-0,26$ & $-0,52$ & 0,93379 & 0,02 & 0,09 & 0,54 & 0,42 \\
PRKAB & $-0,30709$ & 0,03 & 0,11 & $-0,48$ & 0,11 & 0,477273 & $-0,00$ & $-0,04$ & 0,59 & 0,67 \\
SILVR & $-0,38813$ & $-0,13$ & $-0,413$ & $-0,47$ & $-0,98$ & 0,61194 & $-0,01$ & $-0,10$ & 1,06 & $-0,39$ \\
TMSN & $-0,40711$ & $-0,00$ & $-0,00$ & $-0,81$ & $-3,04$ & 0,424444 & 0,00 & 0,00 & $-0,28$ & $-0,43$ \\
TOASO & $-0,48819$ & 0,00 & $-0,06$ & $-2,3$ & $-0,13$ & 0,589349 & 0,01 & $-0,01$ & 0,82 & 0,48 \\
TTRAK & $-0,54079$ & $-0,03$ & $-0,14$ & $-2,84$ & $-1,13$ & 0,587393 & $-0,03$ & $-0,22$ & 1,01 & 0,19 \\
VESBE & 0,256008 & 0,03 & 0,29 & $-0,03$ & $-0,00$ & 0,797005 & $-0,01$ & $-0,02$ & 1,01 & 0,38 \\
VESTL & $-0,26684$ & 0,01 & 0,13 & 0,19 & 0,01 & 1,273874 & $-0,00$ & $-0,02$ & 0,57 & $-0,02$ \\
\hline
\end{tabular}

Çalışmadaki hesaplama sürecinin daha iyi anlaşılabilmesi ve örnek olması bakımından aşağıdaki Tablo 6'da sadece 2015 yılı için firmaların TOPSIS yöntemi ile finansal performans hesaplama sürecinin aşamalarıyla ilgili detaylar gösterilmektedir. Her bir sütundaki F1, F2, F3 ve F4 kriterlerin ( $R O A, R O E, P D / D D$, Altman-Z skoru) normalize edildikten sonra ağırlıklandırılmış halini ifade ederken, $S+$ ve $S$ - ayırma ölçümlerini ve nihayet TOPSIS puanını ifade eden Ci göreceli yakınlığı yani tercih derecelendirme değerini ifade etmektedir. Her bir kriter için gereken pozitif ve negatif ideal değerler ise tabloda matrisin altında ayrı olarak gösterilmiştir. 
Tablo 6: TOPSIS Hesaplama Süreci (2015)

\begin{tabular}{|c|c|c|c|c|c|c|c|}
\hline & F1 & $\mathrm{F} 2$ & F3 & F4 & $\mathrm{S}+$ & S- & $\mathrm{Ci}$ \\
\hline ALCAR & 0,0159071 & 0,009198 & $-0,0085317$ & $-0,0195239$ & 0,2234745 & 0,25975 & 0,5375348 \\
\hline ARCLK & 0,0079536 & 0,0183959 & $-0,0232683$ & $-0,0037071$ & 0,2235254 & 0,2643963 & 0,5418826 \\
\hline ASUZU & $-0,0238607$ & $-0,0229949$ & $-0,0294731$ & $-0,0155697$ & 0,2680468 & 0,2191344 & 0,4498006 \\
\hline AYES & 0,0238607 & 0,0137969 & $-0,0077561$ & $-0,0059313$ & 0,2097683 & 0,2742157 & 0,5665801 \\
\hline BFREN & 0,0556749 & 0,0321928 & 0,0705804 & 0,1045391 & 0,1081812 & 0,4002379 & 0,7872204 \\
\hline DITAS & $-0,1193034$ & $-0,1195734$ & $-0,0449853$ & $-0,0726584$ & 0,4066711 & 0,1128788 & 0,2172627 \\
\hline EGEEN & 0,0079536 & 0,0367918 & 0,0147366 & $-0,163605$ & 0,3146238 & 0,2410122 & 0,4337591 \\
\hline EMKEL & $-0,0079536$ & 0,004599 & $-0,0046537$ & $-0,0051899$ & 0,2291703 & 0,2559931 & 0,5276431 \\
\hline FMIZP & 0,0795356 & 0,0505888 & $-0,1116877$ & 0,0741412 & 0,2303775 & 0,3558113 & 0,606991 \\
\hline FROTO & 0,0159071 & 0,0275939 & $-0,0527414$ & 0,0046956 & 0,2308031 & 0,2703972 & 0,5394992 \\
\hline GEREL & 0,127257 & 0,1057765 & 0,0550682 & 0,0523931 & 0,0719947 & 0,4337409 & 0,8576437 \\
\hline IHEVA & 0 & 0 & $-0,0062049$ & $-0,0056842$ & 0,2276701 & 0,2563546 & 0,5296313 \\
\hline JANTS & $-0,0874892$ & $-0,0735836$ & $-0,0977267$ & $-0,0603015$ & 0,382672 & 0,1201577 & 0,238963 \\
\hline KARSN & 0,0397678 & 0,0643857 & $-0,0046537$ & 0,0032128 & 0,1777481 & 0,3164526 & 0,6403322 \\
\hline KATMR & 0,0318142 & 0,0413908 & 0,0907462 & 0,0308922 & 0,1373813 & 0,3592441 & 0,7233704 \\
\hline KLMSN & 0,0159071 & 0,0413908 & 0,017839 & 0,0051899 & 0,1842842 & 0,3015989 & 0,6207232 \\
\hline OTKAR & $-0,0079536$ & 0,009198 & 0,0209414 & $-0,0076613$ & 0,2172899 & 0,2685058 & 0,5527133 \\
\hline PARSN & $-0,0159071$ & $-0,009198$ & 0,0093073 & $-0,0264437$ & 0,2448933 & 0,2395055 & 0,4944388 \\
\hline PRKAB & 0 & 0 & 0,0635999 & 0,0042013 & 0,1978395 & 0,2975513 & 0,6006395 \\
\hline SILVR & $-0,0954427$ & $-0,1241724$ & $-0,0046537$ & $-0,0042013$ & 0,3553251 & 0,1934816 & 0,3525497 \\
\hline TMSN & 0,0238607 & 0,0137969 & 0,1047072 & 0,0704342 & 0,1425278 & 0,3756761 & 0,7249581 \\
\hline TOASO & 0 & 0,0275939 & 0,0085317 & $-0,0059313$ & 0,2091896 & 0,2767309 & 0,5694983 \\
\hline TTRAK & $-0,0079536$ & 0,009198 & $-0,0093073$ & $-0,0088969$ & 0,2312495 & 0,2541707 & 0,5236096 \\
\hline VESBE & 0,0159071 & 0,0137969 & $-0,0100829$ & $-0,0037071$ & 0,2138996 & 0,2705703 & 0,5584874 \\
\hline VESTL & 0 & $-0,0183959$ & $-0,0380048$ & $-0,0044485$ & 0,2527017 & 0,2370272 & 0,4839968 \\
\hline $\begin{array}{l}\text { Positive } \\
\text { Ideal } \\
\text { Negative }\end{array}$ & 0,127257 & 0,1057765 & 0,1047072 & 0,1045391 & & & \\
\hline Ideal & $-0,1193$ & $-0,12417$ & $-0,11169$ & $-0,1636$ & & & \\
\hline
\end{tabular}

Çalışmadaki hesaplama sürecinin daha iyi anlaşılabilmesi ve örnek olması bakımından aşağıdaki tablo 7'de sadece 2015 yılı için firmaların SAW yöntemi ile finansal performans hesaplama sürecinin aşamalarıyla ilgili detaylar gösterilmektedir. F1, F2, F3 ve F4 kriterlerin (ROA, ROE, PD/DD, Altman-Z skoru) normalize edildikten sonraki ve ağılıklandırılmış halini ifade ederken nihayet toplam değer (the sum) ise SAW puanını ifade etmektedir. 
Tablo 7: SAW Hesaplama Süreci (2015)

\begin{tabular}{|c|c|c|c|c|c|c|c|c|c|}
\hline & Norm F1 & Norm F2 & Norm F3 & Norm F4 & WeightedF1 & WeightedF2 & WeightedF3 & WeightedF4 & The Sum \\
\hline ALCAR & 0,125 & 0,08696 & $-0,0815$ & $-0,1868$ & 0,03125 & 0,02174 & $-0,0204$ & $-0,0467$ & $-0,0141$ \\
\hline ARCLK & 0,0625 & 0,17391 & $-0,2222$ & $-0,0355$ & 0,01563 & 0,04348 & $-0,0556$ & $-0,0089$ & $-0,0053$ \\
\hline ASUZU & $-0,1875$ & $-0,2174$ & $-0,2815$ & $-0,1489$ & $-0,0469$ & $-0,0543$ & $-0,0704$ & $-0,0372$ & $-0,2088$ \\
\hline AYES & 0,1875 & 0,13043 & $-0,0741$ & $-0,0567$ & 0,04688 & 0,03261 & $-0,0185$ & $-0,0142$ & 0,04678 \\
\hline BFREN & 0,4375 & 0,30435 & 0,67407 & 1 & 0,10938 & 0,07609 & 0,16852 & 0,25 & 0,60398 \\
\hline DITAS & $-0,9375$ & $-1,1304$ & $-0,4296$ & $-0,695$ & $-0,2344$ & $-0,2826$ & $-0,1074$ & $-0,1738$ & $-0,7981$ \\
\hline EGEEN & 0,0625 & 0,34783 & 0,14074 & $-1,565$ & 0,01563 & 0,08696 & 0,03519 & $-0,3913$ & $-0,2535$ \\
\hline EMKEL & $-0,0625$ & 0,04348 & $-0,0444$ & $-0,0496$ & $-0,0156$ & 0,01087 & $-0,0111$ & $-0,0124$ & $-0,0283$ \\
\hline FMIZP & 0,625 & 0,47826 & $-1,0667$ & 0,70922 & 0,15625 & 0,11957 & $-0,2667$ & 0,1773 & 0,18645 \\
\hline FROTO & 0,125 & 0,26087 & $-0,5037$ & 0,04492 & 0,03125 & 0,06522 & $-0,1259$ & 0,01123 & $-0,0182$ \\
\hline GEREL & 1 & 1 & 0,52593 & 0,50118 & 0,25 & 0,25 & 0,13148 & 0,1253 & 0,75678 \\
\hline IHEVA & 0 & 0 & $-0,0593$ & $-0,0544$ & 0 & 0 & $-0,0148$ & $-0,0136$ & $-0,0284$ \\
\hline JANTS & $-0,6875$ & $-0,6957$ & $-0,9333$ & $-0,5768$ & $-0,1719$ & $-0,1739$ & $-0,2333$ & $-0,1442$ & $-0,7233$ \\
\hline KARSN & 0,3125 & 0,6087 & $-0,0444$ & 0,03073 & 0,07813 & 0,15217 & $-0,0111$ & 0,00768 & 0,22687 \\
\hline KATMR & 0,25 & 0,3913 & 0,86667 & 0,29551 & 0,0625 & 0,09783 & 0,21667 & 0,07388 & 0,45087 \\
\hline KLMSN & 0,125 & 0,3913 & 0,17037 & 0,04965 & 0,03125 & 0,09783 & 0,04259 & 0,01241 & 0,18408 \\
\hline OTKAR & $-0,0625$ & 0,08696 & 0,2 & $-0,0733$ & $-0,0156$ & 0,02174 & 0,05 & $-0,0183$ & 0,03779 \\
\hline PARSN & $-0,125$ & $-0,087$ & 0,08889 & $-0,253$ & $-0,0313$ & $-0,0217$ & 0,02222 & $-0,0632$ & $-0,094$ \\
\hline PRKAB & 0 & 0 & 0,60741 & 0,04019 & 0 & 0 & 0,15185 & 0,01005 & 0,1619 \\
\hline SILVR & $-0,75$ & $-1,1739$ & $-0,0444$ & $-0,0402$ & $-0,1875$ & $-0,2935$ & $-0,0111$ & $-0,01$ & $-0,5021$ \\
\hline TMSN & 0,1875 & 0,13043 & 1 & 0,67376 & 0,04688 & 0,03261 & 0,25 & 0,16844 & 0,49792 \\
\hline TOASO & 0 & 0,26087 & 0,08148 & $-0,0567$ & 0 & 0,06522 & 0,02037 & $-0,0142$ & 0,0714 \\
\hline TTRAK & $-0,0625$ & 0,08696 & $-0,0889$ & $-0,0851$ & $-0,0156$ & 0,02174 & $-0,0222$ & $-0,0213$ & $-0,0374$ \\
\hline VESBE & 0,125 & 0,13043 & $-0,0963$ & $-0,0355$ & 0,03125 & 0,03261 & $-0,0241$ & $-0,0089$ & 0,03092 \\
\hline VESTL & 0 & $-0,1739$ & $-0,363$ & $-0,0426$ & 0 & $-0,0435$ & $-0,0907$ & $-0,0106$ & $-0,1449$ \\
\hline
\end{tabular}

Aşağıdaki Tablo 8 ve 9'da 2015, 2016, 2017, 2018 ve 2019 yılı için firmaların TOPSIS ve SAW yöntemi ile elde edilen finansal performans sonuçları ve birinci olan firmalar toplu olarak gösterilmektedir. 
Tablo 8: 2015, 2016, 2017, 2018 ve 2019 Yılı İçin Firmaların TOPSIS Ideale Yakınlık Toplam Puanları

\begin{tabular}{lccccc}
\hline & TOPSIS2015 & TOPSIS2016 & TOPSIS2017 & TOPSIS2018 & TOPSIS2019 \\
\hline ALCAR & 0,537535 & 0,647392 & 0,647862 & 0,379436 & 0,266299 \\
ARCLK & 0,541883 & 0,681499 & 0,381293 & 0,412969 & 0,346536 \\
ASUZU & 0,449801 & 0,567579 & 0,421774 & 0,456775 & 0,463803 \\
AYES & 0,56658 & 0,659871 & 0,484328 & 0,446935 & 0,299012 \\
BFREN & 0,78722 & 0,57083 & 0,542604 & 0,504845 & 0,378787 \\
DITAS & 0,217263 & 0,564148 & 0,759246 & 0,486043 & 0,220945 \\
EGEEN & 0,433759 & 0,416853 & 0,602504 & 0,548735 & 0,138351 \\
EMKEL & 0,527643 & 0,641856 & 0,388307 & 0,343104 & 0,560689 \\
FMIZP & 0,606991 & 0,457174 & 0,497351 & $\mathbf{0 , 8 5 4 0 2 2}$ & $\mathbf{0 , 6 1 3 8 1}$ \\
FROTO & 0,539499 & 0,639816 & 0,730581 & 0,415021 & 0,347651 \\
GEREL & $\mathbf{0 , 8 5 7 6 4 4}$ & 0,345332 & 0,736298 & 0,334769 & 0,084333 \\
IHEVA & 0,529631 & 0,5935 & 0,523592 & 0,505713 & 0,573524 \\
JANTS & 0,238963 & 0,645549 & 0,676643 & 0,434173 & 0,410957 \\
KARSN & 0,640332 & 0,578686 & 0,747315 & 0,429258 & 0,401116 \\
KATMR & 0,72337 & 0,496736 & 0,515419 & 0,296375 & 0,398693 \\
KLMSN & 0,620723 & 0,702409 & 0,304283 & 0,555972 & 0,428504 \\
OTKAR & 0,552713 & $\mathbf{0 , 8 3 1 1 5}$ & 0,370042 & 0,412526 & 0,45503 \\
PARSN & 0,494439 & 0,618962 & 0,555061 & 0,38353 & 0,416461 \\
PRKAB & 0,60064 & 0,624985 & 0,448356 & 0,498284 & 0,345311 \\
SILVR & 0,35255 & 0,675345 & $\mathbf{0 , 7 7 4 4 8 6}$ & 0,259819 & 0,304435 \\
TMSN & 0,724958 & 0,552847 & 0,22576 & 0,380318 & 0,348595 \\
TOASO & 0,569498 & 0,670137 & 0,568357 & 0,378807 & 0,37098 \\
TTRAK & 0,52361 & 0,685379 & 0,357702 & 0,27246 & 0,253347 \\
VESBE & 0,558487 & 0,66303 & 0,303268 & 0,544996 & 0,33753 \\
VESTL & 0,483997 & 0,664098 & 0,421904 & 0,505036 & 0,34199 \\
\hline Birinci Firma & $\mathbf{G E R E L}$ & $\mathbf{O T K A R}$ & $\mathbf{S I L V R}$ & $\mathbf{F M I Z P}$ & FMIZP \\
\hline
\end{tabular}

Tablo 9: 2015, 2016, 2017, 2018 ve 2019 Yılı İçin Firmaların SAW Basit Toplam Puanları

\begin{tabular}{|c|c|c|c|c|c|}
\hline & SAW2015 & SAW2016 & SAW2017 & SAW2018 & SAW2019 \\
\hline ALCAR & $-0,01407$ & $-0,1361$ & 0,371069 & $-0,72253$ & $-0,18582$ \\
\hline ARCLK & $-0,00532$ & 0,222914 & $-0,21886$ & $-0,70118$ & $-0,00526$ \\
\hline ASUZU & $-0,20883$ & $-0,78219$ & $-0,13094$ & $-0,13447$ & 0,270078 \\
\hline AYES & 0,046781 & 0,246202 & $-0,02115$ & $-0,14784$ & $-0,11334$ \\
\hline BFREN & 0,60398 & $-0,82478$ & 0,055481 & $-1,45437$ & $-0,05266$ \\
\hline DITAS & $-0,79815$ & $-0,75797$ & 0,649508 & $-0,41731$ & $-0,26021$ \\
\hline EGEEN & $-0,25349$ & $-2,37094$ & 0,300345 & $-0,09844$ & $-0,54677$ \\
\hline EMKEL & $-0,02828$ & 0,101243 & $-0,25069$ & $-0,42569$ & 0,512938 \\
\hline FMIZP & 0,186454 & $-7,11097$ & 0,024773 & 0,705908 & 0,331085 \\
\hline FROTO & $-0,01823$ & $-0,03759$ & 0,506067 & $-1,22212$ & $-0,00078$ \\
\hline GEREL & 0,756777 & $-2,52731$ & 0,519911 & $-1,15593$ & $-0,56248$ \\
\hline IHEVA & $-0,02841$ & $-0,4392$ & 0,073944 & 0,349596 & 0,441439 \\
\hline JANTS & $-0,72333$ & 0,272886 & 0,40061 & $-0,70711$ & 0,147933 \\
\hline KARSN & 0,226871 & $-0,38479$ & 0,566445 & 0,032767 & 0,098451 \\
\hline KATMR & 0,45087 & $-1,36088$ & 0,027083 & $-1,38858$ & 0,091485 \\
\hline KLMSN & 0,18408 & 0,348107 & $-0,4094$ & 0,199984 & 0,179621 \\
\hline OTKAR & 0,037793 & 0,333763 & $-0,21506$ & $-3,58713$ & 0,26042 \\
\hline PARSN & $-0,09401$ & $-0,4156$ & 0,130751 & $-0,3961$ & 0,151845 \\
\hline PRKAB & 0,161899 & $-0,01691$ & $-0,08653$ & $-0,30571$ & 0,003663 \\
\hline SILVR & $-0,50214$ & 0,075079 & 0,644621 & $-0,98969$ & $-0,07351$ \\
\hline TMSN & 0,497923 & $-1,78809$ & $-0,63749$ & $-0,83062$ & $-0,00419$ \\
\hline TOASO & 0,071403 & 0,168773 & 0,158718 & $-2,14087$ & 0,065624 \\
\hline TTRAK & $-0,03738$ & 0,371052 & $-0,27006$ & $-2,81111$ & $-0,17587$ \\
\hline VESBE & 0,030919 & 0,315703 & $-0,39462$ & 0,206712 & $-0,02594$ \\
\hline VESTL & $-0,14486$ & 0,189974 & $-0,15049$ & 0,286948 & $-0,0066$ \\
\hline Birinci Firma & GEREL & TTRAK & DITAS & FMIZP & EMKEL \\
\hline
\end{tabular}


Aşağıdaki tablo 10 'da eşit ağırlıklandırma kullanılmak koşuluyla iki ÇKKV türünün bu veriler ışığında HG ile olan ilişkisinde ürettikleri spearman Rho katsayısı karşılaştırılmaktadır. Buna göre daha iyi ilişki üreten yani daha iyi bir performans sonucu veren ÇKKV yöntemi baskın olarak TOPSIS yöntemidir. Buna göre hem ikili karşılaştırmada hem de yıllara göre Rho ortalamalarında TOPSIS daha yüksek bir performans göstermiştir. Ayrıca standart sapması da daha düşüktür.

Tablo 10: Dönemsel Olarak ÇKKV Sıralamalarının HG Sıralamaları İle Spearman Rho Katsayısı, P Değeri ve Birinci Olan Firmalar.

\begin{tabular}{|c|c|c|c|c|c|c|c|}
\hline & 2019 & 2018 & 2017 & 2016 & 2015 & & \\
\hline \multicolumn{8}{|l|}{$\overline{\text { HG }}$} \\
\hline En İyi & IHEVA & FMIZP & GEREL & KLMSN & KATMR & & \\
\hline TOPSIS & & & & & & Ort. & St. Sap. \\
\hline Rho & 0,482 & 0,638 & 0,815 & 0,824 & 0,711 & 0,694 & 0,12642 \\
\hline$P$ & 0,015 & 0,001 & 0,000 & 0,000 & 0,000 & & \\
\hline En İyi & FMIZP & FMIZP & SILVR & OTKAR & GEREL & & \\
\hline SAW & & & & & & Ort. & St. Sap. \\
\hline Rho & 0,441 & 0,415 & 0,795 & 0,696 & 0,708 & 0,611 & 0,153497 \\
\hline$P$ & 0,027 & 0,039 & 0,000 & 0,000 & 0,000 & & \\
\hline En İyi & EMKEL & FMIZP & DITAS & TTRAK & GEREL & & \\
\hline
\end{tabular}

Yukarıdaki Tablo 10'a göre TOPSIS'in ürettiği sıralamaya göre birinci olan (en iyi) firma diğer yöntem olan SAW ile 2015 ve 2018'de aynı iken diğer üç yılda farklıdır. TOPSIS ve SAW tüm firmalar için düşünüldüğünde genelde uyumlu bir sıralama ürettikleri halde beş dönemin üçünde farklı birinci firma üretmişlerdir. Yani ÇKKV yöntemleri benzer sıralama üretebilir ama bu en iyi olan firmanın iki yöntem için de aynı olacağını garanti etmemektedir. Birinci olan firma ÇKKV'ler için önemlidir çünkü ÇKKV yöntemlerinin esas amacı en iyi olan alternatifi (ve sıralamayı) önermektir. Başka bir ifadeyle iki yöntem arasındaki yüzde yüz olmayan yüksek benzerlik diğer istatistiki yaklaşımlarda anlamlı bir fark olmadığı algısına yol açarken ÇKKV paradigması için aradaki fark çok anlamlıdır. Çünkü ÇKKV yaklaşımında kritik nokta en iyi olan alternatifin hangisi olduğudur. Kısaca ÇKKV yöntemlerinde araştırmacılar için tüm mücadele ve çaba en iyi olan alternatifin tespiti içindir. Aşağıdaki şekil 2'de ÇKKV ile hesaplanan FP ile HG arasındaki korelasyon ilişkileri (Rho) çubuk grafiğinde ayrı ayrı görülmektedir.

Şekil 2: ÇKKV ve HG Sıralamaları Arasındaki İlişki

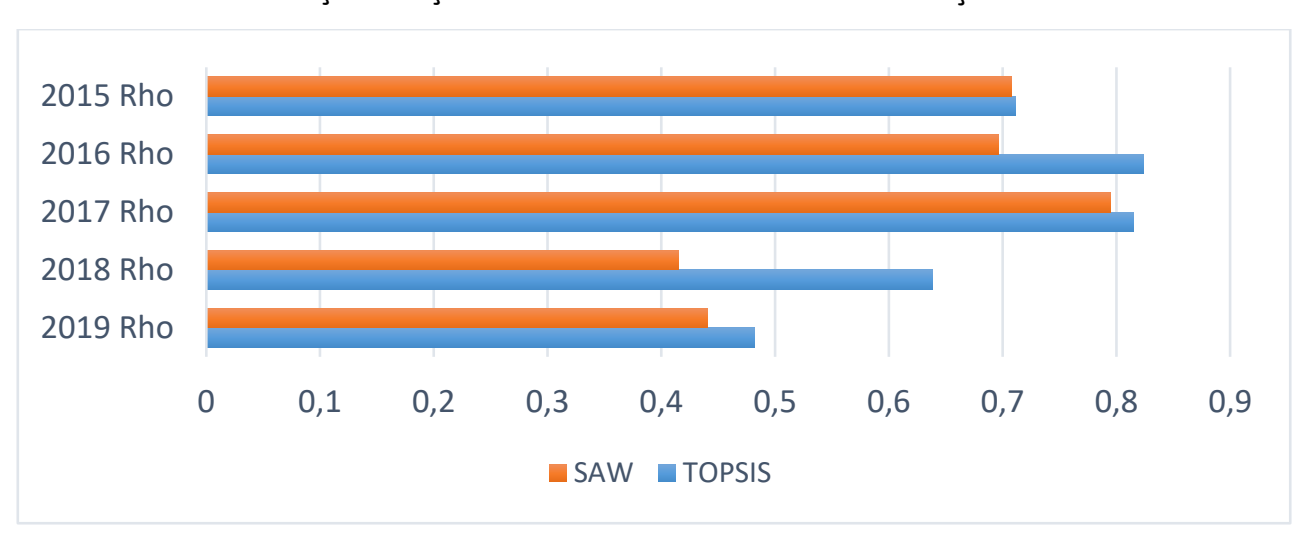


Diğer taraftan TOPSIS ve SAW yöntemlerinin bazı yıllarda (2015 ve 2017) birbirlerine çok benzer Rho ürettikleri ve diğer yıllarda ise aradaki makasın açıldığı görülmektedir. Bu durumun verilerin yapısı, kullanılan normalizasyon ve toplama yöntemleriyle ilgili olması muhtemeldir. SAW ve TOPSIS farklı normalizasyon yöntemleri kullanır. Yani küçük düzeyde de olsa sonuçları etkileyebilecek normalizasyondan kaynaklı bilginin kaybı iki yöntem için farklıdır. Diğer taraftan TOPSIS ideal pozitif (yani maksimum) ve ideal negatif (yani minimum) değerlere daha bağımlıdır. Bu değerler TOPSIS sonuçları için belirleyicidir. Bazı yıllarda ideal değerlerin astronomik bir şekilde yükselmesi ya da düşmesi TOPSIS sonuçlarını daha fazla etkilemektedir. Zaten ÇKKV için klasik bir problem olan sıranın tersine çevrilmesi problemi (rank reversal) TOPSIS için daha güçlü bir problemdir. Nedeni ise TOPSIS yaklaşımının ideal değerleri daha çok önemsemesidir. Yukarıda şekil 2'ye tekrar döndüğümüzde, TOPSIS yönteminin SAW yöntemine göre tüm baz dönemlerde baskın bir biçimde daha başarılı bir performans gösterdiği kolaylıkla görülebilmektedir. Grafiğe göre 2017 ve sonrasındaki yıllarda FP ile HG arasındaki korelasyonların her iki yöntemde de azaldığı anlaşılmaktadır. Söz konusu yıllarda sistematik risk unsurlarının FP'ye göre hisse fiyatlarında daha etkili olduğu söylenebilir. Başka bir ifadeyle ekonomik volatilitenin yükseldiği dönemlerde HG ile FP ilişkisi olarak azalmış olabilir. Bu da bazı dönemlerde firmanın içsel başarısının dışsal piyasada daha az karşılık bulduğu anlamına gelmektedir.

Analiz bulgularına göre buradaki yaklaşım, daha önceki çalışmalardan farklı olarak ÇKKV yöntemlerini yetenek ve kapasitelerine göre değil ürettikleri sonuçlara göre değerlendirmiştir. Buna göre ÇKKV yöntemleri bir ölçüde birbirlerine üstünlük sağlayabilmektedirler. Başka bir ifadeyle bir yöntemin diğerine göre daha uygun olabileceği söylenebilir. Nitekim bulgulardan TOPSIS yönteminin gerçek bir yaşam sıralaması olan HG ile daha yüksek derecede benzerlik sağlayabildiği anlaşılmaktadır. Başka bir ifadeyle TOPSIS var olan bir ilişki potansiyelini SAW yöntemine göre daha yüksek derecede ve daha doğru sağlamaktadır. Bunun derinlikli nedenleri başka bir araştırma konusudur.

HG ile ideal Değerler ve Normalizasyon Tipi iliş̧kisi

Diğer taraftan SAW yönteminin doğrusal maksimum normalizasyon ve basit toplam yöntemi ile sonuçları ürettiği göz önüne alınmalıdır. İdeal değerlere yakınlık/uzaklık varsayımının TOPSIS yöntemini üstün kılabilecek önemli bir etki faktörüne sahip olduğu düşünülebilir. Etkilerin sonuçlarını görebilmek artık mümkündür. Dolayısıyla sonuçlar üzerinde SAW yöntemi için normalizasyon türünün ve TOPSIS'te ise ideal değerlerin etkisine bakılabilir. Hem bu iki kritik hususa cevap verebilmek ve hem de farklı yöntemlerle karşılaştırmalara geçerlilik ve derinlik katabilmek için LINMAP ve WSA yöntemleri de karşılaştırmaya eklenerek sonuçlar değerlendirilmiştir. Esasen LINMAP, TOPSIS yönteminden türetilen bir yöntemdir. LINMAP sadece İdeal pozitif değere uzaklığı (S+) ifade ederken TOPSIS hem negatif hem de pozitif ideal değere uzlaşık uzaklığı (Ci) ifade eder. WSA yöntemi ise SAW yönteminden türetilmiştir. Aradaki tek fark kullandıkları normalizasyon türüdür. SAW doğrusal maksimum normalizasyon kullanırken WSA doğrusal min-maks normalizasyonunu kullanır. Bu yöntemler hem ayrı yöntemler ve hem de kendi familyasının benzeri yöntemleridir. 
Tablo 11: Dönemsel Olarak Farklı ÇKKV Sıralamalarının HG Sıralamaları İle İlişkisi

\begin{tabular}{lcccccccc} 
& $\mathbf{2 0 1 9}$ & $\mathbf{2 0 1 8}$ & $\mathbf{2 0 1 7}$ & $\mathbf{2 0 1 6}$ & $\mathbf{2 0 1 5}$ & & \\
\cline { 1 - 7 } & $\mathbf{2 0 1 9}$ Rho & $\mathbf{2 0 1 8}$ Rho & $\mathbf{2 0 1 7}$ Rho & $\mathbf{2 0 1 6}$ Rho & $\mathbf{2 0 1 5}$ Rho & Ort. & St. Sap. \\
\hline 1.LINMAP & 0,563 & 0,59 & 0,823 & 0,875 & 0,708 & 0,7118 & 0,123281 \\
\hline 2.TOPSIS & 0,482 & 0,638 & 0,815 & 0,824 & 0,711 & 0,694 & 0,12642 \\
\hline 3.WSA & 0,538 & 0,628 & 0,782 & 0,753 & 0,734 & 0,687 & 0,090854 \\
\hline 4.SAW & 0,441 & 0,415 & 0,795 & 0,696 & 0,708 & 0,611 & 0,153497 \\
\hline
\end{tabular}

Yukarıdaki Tablo 11'e göre şu objektif değerlendirmeler yapılabilir:

- Bu veriler ve şartlar için geçerli olmak koşuluyla TOPSIS'ten türetilen LINMAP daha yüksek Rho korelasyonu ürettiğinden TOPSIS'e göre daha iyi bir performans göstermiştir. Bu durum ideal pozitif değere uzaklık (S+) sıralamalarının TOPSIS'e (Ci) göre iyi ve yeterli bir alternatif olduğunu göstermektedir.

- WSA yönteminin SAW yöntemine göre daha yüksek Rho üretmesi açıkça normalizasyon türlerinin ÇKKV yöntemlerinin performansını etkilediğini göstermektedir. Buna göre diğer unsurlar aynı kaldığı için minumum-maksimum normalizasyon türü maksimum normalizasyon türüne göre daha yüksek performans göstermiştir denebilir.

- LINMAP yönteminin ürettiği yüksek ilişki katsayısı olan ortalama Rho değeri göz önüne alındığında bu uygulamadaki mevcut yöntemler arasında en başarılı ÇKKV yöntemi olduğu söylenebilir. Dolayısıyla bu veri, ölçüt ve bu şartlar için LINMAP yöntemi genel olarak karar vericiye önerilmektedir. Önerilen yöntem otomotik olarak yani insan unsuruna bırakılmadan seçildiği için bu seçim şeklinin literatürden farklı olarak objektif bir seçim olduğu değerlendirilmektedir.

- Diğer taraftan ÇKKV seçiminde 5 yıllık ortalamaya göre mi yoksa tek yıllık değerlere göre mi hareket edilmesi gerektiği bir tartışma konusu olabilir. Bu noktada genel başarı performansı için bir fikir edinebilmek adına 5 yıllık üretilen Rho ortalamasına; ÇKKV seçimi için ise yıl performansı baz alınabilir. Birinci durumda başarılı olan yöntemin sabit ve ikinci durumda ise değişken olduğuna dikkat edilmelidir.

\section{Sonuç}

Yarım asrı aşkın bir süredir ÇKKV yöntemleri pek çok problemi çözmek amacıyla kullanılmaktadır. Bu süreçte ÇKKV sonuçlarına göre, hangi yöntemin seçilmesi gerektiği ile ilgili nihai bir mutabakat, objektif bir biçimde geliştirilememiştir. Bilindiği gibi ÇKKV yöntemlerinin esas amacı "en iyi" olan alternatifi seçmek yani birinci olanı belirlemek olduğu için sıralamaların yüksek benzerlikte olması esasen ÇKKV yaklaşımında çok da anlamlı ve önemli değildir. En iyi alternatif seçilmediğinde (örneğin yatırımcı için) bunun 'alternatif maliyet'i yüksek olabilmektedir. Bu açıdan uygun ÇKKV yöntemini seçmek karar verici için çok önemlidir.

Bu çalışmada finansal performans ile hisse getirisi arasındaki ilişkiyi daha iyi sağlayan ÇKKV modelinin seçilmesinin kullanıcı açısından daha uygun ve verimli olacağı objektif olarak önerilmektedir. Bazı ÇKKV yöntemleri var olan bir ilişkiyi diğerlerine göre daha iyi sağlayabilir ve bu durum bazı yöntemlerin gerçeklikle ilişkisinin daha iyi olduğunu ima eder. Dolayısıyla bu mevcut verilerle özellikle hissedar değerine odaklı bir finansal performans ölçmek isteyen, TOPSIS ve SAW yöntemleri arasında bir tercih yapması gereken karar vericinin, TOPSIS yöntemini tercih etmesi kesinlikle önerilmektedir. Çünkü TOPSIS tüm baz dönemlerde söz konusu ilişkiyi daha yüksek üretmiştir. SAW yöntemi için var olan ilişkinin bir kısmının kayıp 
olduğu anlaşılmaktadır. Vakaya TOPSIS'ten türetilen LINMAP ve SAW'dan türetilen WSA'yı eklendiğinde LINMAP yönteminin öne çıktığı görülmektedir. Bu durum aynı zamanda ideal değerler ile ölçüm yapan TOPSIS ve LINMAP ailesinin basit toplamlı WSA ve SAW ailesinden daha başarılı olduğunu göstermektedir. Normalizasyon türü olarak min-max normalizasyonu, max normalizasyona göre daha başarılı olduğu söylenebilir.

Bilindiği üzere ÇKKV yöntemleri pek çok karar verici tarafından popülerlik, yazılım desteği, yaygın benimsenme ve hatta keyfilik gibi sübjektif nedenlerle seçilebilmektedir. Bu çalışmada hisse fiyatı referansıyla önerilen objektif yaklaşım mutlak anlamda olmasa da mevcut şartlardaki verilerle hangi ÇKKV yönteminin kullanılması gerektiği ile ilgili 'dolaylı' ama somut bir ölçüt önermektedir. Gelecekte dijitalleşmedeki dönüşüme paralel olarak gerçekleşmesi umulan sayısız gelişmeden biri de ÇKKV hesaplama sürecindeki sübjektif karar verme alanlarını azaltmaktır. Bu yönüyle de çalışmanın literatüre kayda değer bir katkısının olması beklenir.

\section{Sinırlılıklar}

Bu çalışma gelişmekte olan bir piyasa olan Türkiye'deki Borsa İstanbul'da yapılmıştır. Ayrıca 2015-2019 periyotlarında yapılmıştır. 25 firma için 4 kriterle performans ölçüm sistemi uygulanmıştır. Söz konusu zaman, yer, karar kriterleri ve firma sayısı çalışmanın kısıtlılıklarıdır. Dolayısıyla bu kısıtlar altında çalışmanın sonuçları değerlendirilmelidir.

\section{Gelecek Araştırmalar İcin Öneriler}

Gelecekteki araştırmacılar finansal performans ölçümü için çalışmada önerilen yaklaşımı kullanarak daha fazla alternatif, kriter, ÇKKV ve ağırlıklandırma yöntemlerinin olduğu kapsamlı analizler yapabilirler. İkinci olarak araştırmacılar bazı ÇKKV yöntemlerinin neden daha yüksek Rho ürettiğini, matematiksel prosedüre yoğunlaşarak izah edebilirler. Üçüncü olarak yöneylem araştırması, mühendislik ve bilişim gibi diğer uygulamalı alanlarda da ÇKKV sonuçlarıyla ilişkili gerçek yaşamdan proxy bir sıralamanın varlığı saptanabilirse bu çalışmadaki yaklaşım daha da genelleştirilebilir. 


\section{Kaynakça}

Ban, A.I.; Ban O.I.; Bogdan, V.; Sabau Popa, D.C.; Tuse, D. (2020), "Performance Evaluatıon Model of Romanıan Manufacturıng Listed Companies by Fuzzy AHP and TOPSIS", Technological and Economic Development of Economy, Vol. 26, No. 4, 808-836.

Bayrakdaroğlu, A.; Yalcin, N. (2012), "Strategic Financial Performance Evaluation of the Turkish Companies Traded on ISE", Ege Akademik Bakış, Vol. 12, No. 4, 529-539.

Bodie, Z.; Kane, A.; Marcus, J. A. (2018), Yatırımın Temelleri, Mc Graw Hill: Nobel Akademik Yayıncılık, Çev. Ed: Sezgin Demir, 14.Bölümü Çev: Abdullah Bayram.

Carton, R. B. (2004), Measuring organizational performance: an exploratory study, Unpublished Doctoral Dissertation, The University of Georgia, Athens.

Carton, R. B.; Hofer, C. W. (2006), Measuring Organizational Performance - Metrics for Entrepreneurship and Strategic Management Research, Cheltenham UK/Northampton USA: Edward Elgar Publishing Limited.

Çabuk, A.; Lazol, i. (2005), Mali Tablolar Analizi, 1. Baskı, İstanbul: Nobel Yayınları.

Çınar, Y. (2004), Çok Nitelikli Karar Verme ve Bankaların Mali Performanslarının Değerlendirilmesi Örneği, Yayınlanmamış Yüksek Lisans Tezi, Ankara Üniversitesi Sosyal Bilimler Enstitüsü, Ankara.

Danesh, D.; Ryan, M. J.; Abbasi, A. (2017), "A systematic comparison of multi-criteria decision making methods for the improvement of project portfolio management in complex organisations", International Journal of Management and Decision Making, Vol. 16, No. 3, 280-320.

De Almeida-Filho, A. T.; De Lima Silva, D. F.; Ferreira L.; (2020), "Financial modelling with multiple criteria decision making: A systematic literatüre review", Journal of the Operational Research Society, DOI: 10.1080/01605682.2020.1772021, 1-19.

Feng, C. M.; Wang, R. T. (2000), "Performance evaluation for airlines including the consideration of financial ratios", Journal of Air Transport Management, Vol. 6, 133-142.

Hoe, L.W.; Siew, L.W.; Fail, L.K.; Xin A.L.J.; Fun, P. (2020). "An empirical evaluation on the performance of food service industry in Malaysia with TOPSIS model", First International Conference on Advances in Physical Sciences and Materials https://iopscience.iop.org/article/10.1088/17426596/1706/1/012172/pdf (Erişim: 10.03.2021)

Javadin, S.R.S.; Esbouei, S.K.; Rajabani, N. (2016), “An Integrated Assessment of Companies Based on Value based Measures in Fuzzy Environment", Boletim da Sociedade Paranaense de Matemática, Vol. 34, No. 2, 87-98.

Kayahan Karakul, A.; Özaydın, G. (2019), "TOPSIS ve VIKOR Yöntemleri ile Finansal Performans Değerlendirmesi: XELKT Üzerinde Bir Uygulama”, Dumlupınar Üniversitesi Sosyal Bilimler Dergisi, No. 60, 68-86.

Özçelik, H.; Kandemir, B. (2015), "BIST'de İşlem Gören Turizm İşletmelerinin TOPSIS Yöntemi ile Finansal Performanslarının Değerlendirilmesi", Balıkesir Üniversitesi Sosyal Bilimler Enstitüsü Dergisi, Vol. 18, No. 33, 97-114.

Özden. Ü. H.; Deniz Başar, Ö.; Bağdatlı Kalkan. S. (2012), “iMKB'de İşlem Gören Çimento Sektöründeki Şirketlerin Finansal Performanslarının VIKOR Yöntemi ile Sıralanması", istanbul Üniversitesi iktisat Fakültesi iktisat Fakültesi Ekonometri ve istatistik Dergisi, No. 17, 23-44.

Sakarya, Ş.; Yıldırım, H.H. (2016), "Borsa İstanbul'da İşlem Gören Enerji Şirketlerinin Finansal Performansları ile Hisse Senedi Getirileri Arasındaki İlişkinin Panel Veri Analizi İle Belirlenmesi", Journal of Economics, Finance and Accounting, Vol. 3, No. 1, 71-88.

Stewart, B. (2013), Best-Practice EVA: The Definitive Guide to Measuring and Maximizing Shareholder Value, New York: John Wiley \& Sons. 
Şahin, A.; Sarı, E. B. (2019), “Entropi Tabanlı Topsis ve Vikor Yöntemleriyle BiST-İmalat İşletmelerinin Finansal ve Borsa Performanslarının Karşılaştırılması", Muhasebe ve Vergi Uygulamaları Dergisi, Vol. 12, No. 2, 255-270.

Şen, S. (2014), Farklı Ağırlıklandırma Tekniklerinin Denendiği Çok Kriterli Karar Verme Yöntemleri Ile Türkiye'deki Mevduat Bankalarının Mali Performans Değerlendirmesi, Yayınlanmamış Yüksek Lisans Tezi, Mimar Sinan Güzel Sanatlar Üniversitesi Fen Bilimleri Enstitüsü, İstanbul.

Şit, A.; Ekşi, I.H.; Helvacıgil, N. (2017), “BIST'te Ana Metal Sanayi Endeksinde Faaliyet Gösteren İ̧̧letmelerin Finansal Performans Ölçümü: 2011-2015 Dönemi”, Süleyman Demirel Üniversitesi Vizyoner Dergisi, Vol. 8, No. 17, 83-91.

Triantaphyllou, E. (2000), Multi Criteria Decision Making Methods: A Comparative Study, London: Kluwer Academic Publishers.

Wang, Z.; Rangaiah, G. P. (2017), “Application and analysis of methods for selecting an optimal solution from the Pareto-Optimal front obtained by multiobjective optimization", Industrial \& Engineering Chemistry Research, No. 56, 560-574.

Yaakob, A. M.; Serguieva A.; Gegov A. (2017), “FN-TOPSIS: Fuzzy Networks for Ranking Traded Equities", IEEE Transactıons On Fuzzy Systems, Vol. 25, No. 2, 315-332. 


\section{An Objective Approach to the MCDM Method Selection Problem in Financial Performance Measurement: An Application in Borsa Istanbul}

With the increasing global competition, improving information communication, and digitalization, the importance of appropriate financial performance measurement (FP) for companies is increasing. In FP measurements calculated with Multi Criteria Decision Making (MCDM) methods, which started in the 2000s, it is seen that the subjective factors are tried to be reduced for a more objective result. In general, studies have made objective recommendations in structuring some stages to minimize this situation. The MCDM literature can be summarized in efforts to minimize subjectivity and maximize objectivity in decision-making. In other words, it can be said that the common purpose of past studies is to improve the non-optimal MCDM procedure. It becomes more important to be objective and therefore to achieve compromise solution results closer to the optimum solution.

The choice of the MCDM method in FP measurement is almost like one of the subjective decision stages in practice. This choice is a problem and a real concern not only for financial performance researchers but also for all applied scientists using MCDM methods. As it is known, the choice of an MCDM method is determined by the decision-maker (DM) since there is no objective solution as to which MCDM method is better. DM's choice to choose the MCDM method directly affects the FP measurement results. Therefore, choosing a suitable MCDM method can be considered a very important problem that should be considered.

As it is known, in the financial performance studies achieved with MCDM so far, MCDM methods have been compared with each other only based on 'capacity' or 'ability' criteria. We rarely come across comparisons on the 'value' or 'result' produced by MCDM methods. What does it mean that different MCDM methods produce different rankings, a situation that MCDM researchers often encounter? Studies show that giving positive or negative meaning to an MCDM ranking is one of the most difficult and avoided aspects of such studies. It was not possible to determine a better MCDM method as a reasonable reference point could not be found in comparing the MCDM methods according to the sequencing results.

As a different approach, in this study, the results of MCDM applications are compared according to their degree of similarity to an external ranking obtained from real life. The degree of statistical relationship between the stock return (SR), which expresses the price change in the stock market of firms with a real-life ranking, and the simultaneous financial performance rankings of the same firm is the singular comparison criterion for MCDMs in this study.

Accordingly, the simplest way to evaluate different MCDM rankings is to compare them to real-life rankings that produce a similar ranking. It is important and recommended that this singular ranking is a real-life ranking. On the other hand, in this study, this singular ranking refers to a second and different purpose for alternatives. So while achieving good financial performance is one goal for a firm, a good positive SR is also a second goal. Here, MCDM methods are classified over these two related purposes. Therefore, in this study, a quantitative criterion regarding which MCDM method should be chosen for decision-makers who want to measure financial performance with any of the MCDM methods is proposed. It is thought that the original approach in the study will help the problem of MCDM selection, which is a concern for decision-makers.

If we need to sum up the approach in the study in a single sentence, it can be stated as follows: The MCDM method, which provides a stronger statistical similarity relationship between the firms' FP rank calculated by MCDM methods and SR return rank, is recommended to the decision-maker. To test this approach, the annual financial performance of 25 firms from the Metal Goods sector, which is one of the Borsa Istanbul Manufacturing sub-sectors, was measured. TOPSIS and SAW methods were used based on certain decision criteria. The study covers the periods of 2015-2019. In the next stage, the relationship between stock return and financial performance is calculated with the Spearman correlation coefficient. TOPSIS and SAW methods were compared in terms of correlation results with SR.

On the other hand, some MCDM methods follow a more tolerant calculation process for DM participation. These methods may ask the DM to determine their assumption, threshold value, or preference functions as they wish in certain constraints. Conversely, DM intervention is less in some methods (TOPSIS, SAW, etc.). Therefore, whatever method is used, the decision-maker has a participatory power to directly affect the results. However, the MCDM method that provides the highest degree of correlation between SR and FP can be recommended to DM. Thus, unlike previous studies, the MCDM method will be determined "automatically" by this approach in the study, not by individuals or experts.

According to the results of the study, the TOPSIS method showed a better performance than the SAW method on the basis of both year-based pairwise comparisons and the average correlation produced in the relationship between FP and SR. Among the MCDM methods used in the study, TOPSIS can be said to be more successful because it resembles SR more than the SAW method, that is, it produces a higher correlation. It can be said that the TOPSIS method could have been expected to be more successful than the SAW method, which is a more primitive and simpler method. Because the TOPSIS method concentrates on ideal solutions and is also better equipped in terms of mathematical capacity. However, the clear success of TOPSIS in terms of objective results should be considered as the original approach of this study. It is thought that working with this different approach when comparing MCDMs will be useful for solving an MCDM method selection problem for FP and will contribute to the literature. 